\title{
REVIEW
}

\section{Sustainability, biomass yields, and health of coastal ecosystems: an ecological perspective}

\author{
Kenneth Sherman
}

\begin{abstract}
National Oceanic and Atmospheric Administration, National Marine Fisheries Service, Northeast Fisheries Science Center, Narragansett Laboratory, Narragansett, Rhode Island 02882-1199, USA
\end{abstract}

\begin{abstract}
The sustainability, health and biomass yields of marine resources can be enhanced by the implementation of a more holistic and ecologically based strategy for assessing, monitoring, and managing coastal ecosystems than has been generally practiced during most of this century. A major milestone was reached in advancing toward a more ecologically based management practice when the majority of coastal nations of the world endorsed the declaration made at the United Nations Conference on Environment and Development (UNCED) in 1992, to prevent, reduce, and control degradation of the marine environment, so as to maintain and improve its life-support and productive capacities; develop and increase the potential of marine living resources to meet human nutritional needs, as well as social, economic, and development goals; and promote the integrated management and sustainable development of coastal areas and the marine environment. The scientific framework in support of the UNCED objectives is now emerging from a series of regional efforts aimed at cross-sectoral integration of research, monitoring, and assessments conducted to mitigate stresses on coastal ecosystems from toxic effluents, habitat degradation, nutrient loadings, harmful algal blooms, aerosol contaminants, and losses of living resources from pollution and overexploitation. Discipline-oriented ecological studies can contribute more toward achievement of resource sustainability when they are conducted within a framework of science at the level of organization that is multidisciplinary and focused on populations, habitats, and ecosystems at large spatial scales. Primary, secondary, and tertiary driving forces of variability in biomass yields are examined for several large marine ecosystems, along with observations on changing states of 'health' of the systems. Marine resource problems underscored by UNCED are being addressed. Post-UNCED large marine ecosystem-scale programs for advancement toward resource sustainability, ecosystem health, and economically viable biomass yields are now being implemented. The programs are being supported by international agencies as part of an effort to couple recent advances in ecological monitoring, management, and stress mitigation strategies from the more developed countries, with the lesser developed coastal countries around the margins of the ocean basins.
\end{abstract}

KEY WORDS: Marine resources - Sustainability - Assessment - Management - Large marine ecosystems · Biomass yields

\begin{abstract}
Environmental degradation is not inevitable; it is simply cheaper and easier for some in the short term. Environmental health also is not inconsistent with economic imperatives and political realities. In fact, a healthy environment is the basis for a healthy economy. Ecosystem ecology provides an important and useful approach both for assessing and for helping to restore the 'health' of the biosphere.

G. E. Likens (1992)
\end{abstract}

\section{ECOSYSTEM SUSTAINABILITY}

Human intervention and climate change are sources of additional variability in the natural productivity of coastal marine ecosystems. Within the nearshore areas and extending seaward around the margins of the global land masses, coastal ecosystems are being subjected to increased stress from toxic effluents, habitat degradation, excessive nutrient loadings, harmful algal blooms, emergent diseases, fallout from aerosol conta- 
minants, and episodic losses of living marine resources from pollution effects, and overexploitation. The longterm sustainability of coastal ecosystems as sources for healthy economies appears to be diminishing. A growing awareness that the quality of the global coastal ecosystems are being adversely impacted by multiple driving forces has accelerated efforts to assess, monitor, and mitigate coastal stressors from an ecosystem perspective. The Intergovernmental Oceanographic Commission (IOC) of the United Nations Educational, Scientific, and Cultural Organization (UNESCO) is encouraging coastal nations to establish national programs for assessing and monitoring coastal ecosystems, so as to enhance the ability of national and regional management organizations to develop and implement effective remedial programs for improving the quality of degraded ecosystems (IOC 1992a). This encouragement follows from the significant milestone achieved in July 1992 with the adoption by a majority of coastal countries of follow-on actions to the United Nations Conference on Environment and Development (UNCED). The UNCED declarations on the ocean explicitly recommended that nations of the globe: (1) prevent, reduce, and control degradation of the marine environment so as to maintain and improve its life-support and productive capacities; (2) develop and increase the potential of marine living resources to meet human nutritional needs, as well as social, economic, and development goals; and (3) promote the integrated management and sustainable development of coastal areas and the marine environment. UNCED also recognized the general importance of capacity building, as well as the important linkage between monitoring the changing states or 'health' of coastal ecosystems and the achievement of marine resource sustainability and developmental goals.

The concept of sustainability as applied to marine resources and ecosystems has been the subject of recent debate. In a recent work, Ludwig et al. (1993) argue that basic research in ecology to be conducted in support of the Sustainable Biosphere Initiative of the Ecological Society of America (Lubchenco et al. 1991) may be leading to complacency, as the most pressing issues being addressed to avoid further degradation of global renewable resources are increasing human populations and excessive use of resources, not necessarily more scientific research. They support their arguments with citations of: (1) the apparent failures in fisheries management to maintain ecologically balanced stock viability in the face of increasing fishing effort, and (2) that claims of sustainability were suspect as populations are overexploited because scientific consensus on resource status is difficult to obtain. Rosenberg et al. (1993) dispute the Ludwig et al. (1993) assertions and maintain that 'fisheries manage- ment provides positive examples of sustainable resource use and lessons for future improvements'. They argue that 'there is a sound theoretical and empirical basis for sustainable use of marine resources, that overexploitation is not inevitable, or the result of inadequate scientific advice, and that sustainable use of renewable resources is an obtainable management objective'. In the development of a sustainable harvesting management regime, Rosenberg et al. (1993) emphasize the need for taking into account environmental conditions and exploitation rates by implementing appropriate monitoring programs to identify and track the shifts in population responses. They conclude that sustainable development of marine resources is achievable if scientific advice based on biological, social, and economic considerations is an integral part of the development of policies for renewable resource use. This conclusion is in agreement with Mangel et al. (1993), who argue that 'sustainable use' of renewable resources is achievable when humans use living components of ecosystems in ways that allow natural processes to replace what is used. Under these conditions, the ecosystem 'will renew itself indefinitely and human use will be sustainable'.

An ecosystems approach for ecologists interested in contributing toward a scientifically based strategy for resource sustainability is given by Holling (1993). He emphasizes the need to recognize that there is an emerging science that is multidisciplinary and focused on populations and ecosystems on large spatial scales that include socioeconomic considerations in planning and implementation appropriate to the issue of resource sustainability. The more traditional, but nonetheless important, disciplinary oriented ecological studies can contribute more to resource sustainability when they are conducted within a framework of science at the level of organization that is multidisciplinary and focused on issues affecting populations within an ecosystems perspective. The international GLOBEC regional programs (Skjoldal et al. 1993), the International Geosphere-Biosphere Program on the Land-Oceans Interaction in the Coastal Zone Program (IGBP 1994) and Joint Global Ocean Flux Study (IGBP 1994) are examples of the newly emerging large-scale multidisciplinary marine ecosystem science. Linkages between these process-oriented studies and the more applied studies that are focused on supporting the sustainability of marine resources are being encouraged by national and international funding agencies concerned with the sustainability of natural resources. In this regard, the definition of sustainability used by Holling and carried forward in this perspective focuses on ecosystem studies in support of 'the social and economic development of a region with the goals to invest in the maintenance and restoration of critical ecosys- 
tem functions, to synthesize and make accessible knowledge and understanding for economies, and to develop and communicate the understanding that provides a foundation of trust for citizens' (Holling 1993).

In practice, therefore, it would be important to establish institutional arrangements for ensuring that appropriate socioeconomic considerations are exercised in the application of science in support of regimes aimed at the sustainability of renewable resources. Regional examples of this approach to ecosystem sustainability can be found in the objectives of the Convention for the Conservation of Antarctic Living Marine Resources (Scully 1993), and the ministerial declarations for the protection of the Black Sea (Hey \& Mee 1993), and the North Sea (NSTF 1991). The Black Sea Declaration refers specifically to the objectives of UNCED Agenda 21, Chapter 17, that calls for integrated management and sustainable development of coastal areas, marine environmental protection, sustainable use and conservation of living resources under national jurisdiction, and the need for addressing critical uncertainties for the management of the marine environment and strengthening of international and regional cooperation and coordination (Hey \& Mee 1993). An effort to develop a management system for the Barents Sea Ecosystem that provides stronger links between science and socioeconomic considerations from an ecosystems perspective is under consideration (Eikeland 1992).

\section{LARGE MARINE ECOSYSTEMS CONCEPT}

An essential component of an ecosystem management regime is the inclusion of a scientifically based strategy that monitors and assesses the changing states and health of the ecosystem by tracking key biological and environmental parameters. From this perspective, marine ecosystem assessment and monitoring is defined as a component of a management system that includes: (1) regulatory, (2) institutional, and (3) decision-making aspects relating to marine ecosystems, and therefore, would include a range of activities needed to provide management information about ecosystem conditions, contaminants, and resources at risk. Based on experiences in North America, Europe, and elsewhere, the core component of a comprehensive coastal ecosystem assessment and monitoring system that consists of conceptual and numerical modelling capability, laboratory and field research, time-series measurements, data analysis, synthesis and interpretation, and a capacity for initiating the effort with preliminary or scoping studies is most likely to be successful (NRC 1990). The principal characteristic of a comprehensive ecosystem assessment and monitoring program is the integration and coordina- tion of the component parts of the effort into a total ecosystems approach designed to produce scientific information in support of coastal resources management.

This strategy is consistent with the conclusion that monitoring efforts at the regional scale need to be strengthened to improve understanding of broaderscale trends in marine ecosystem quality. Several recent reports that address these issues have been consulted in the preparation of this perspective, including the United Nations' report on the status of the global marine environment (GESAMP 1990), the IOC's report on the Global Ocean Observing System (GOOS) presented to the UNCED in 1992 (IOC 1992a), the reports of several international commissions, including the Helsinki Commission (HELCOM), the Oslo-Paris Commission (OSPARCOM), the North Sea Task Force (NSTF 1991), and the report of the International Council for the Exploration of the Sea (ICES) Working Group on Environmental Assessments and Monitoring Strategies (WGEAMS 1992).

Mitigating actions to reduce stress on marine ecosystems are required to ensure the long-term sustainability of marine resources. The principles adopted by coastal states under the terms of the United Nations Convention for the Law of the Sea (UNCLOS) have been interpreted as supportive of the management of living marine resources and coastal habitats from an ecosystems perspective (Belsky 1986, 1989). However, at present no single international institution has been empowered to monitor the changing ecological states of marine ecosystems and to reconcile the needs of individual nations with those of the community of nations in taking appropriate mitigation actions (IUCN 1990, Myers 1990). In this regard, the need for a regional approach to implement research, monitoring, and stress mitigation in support of marine resources development and sustainability at less than the global level has been recognized from a strategic perspective (Taylor \& Groom 1989, Malone 1991, Hey 1992). Achievement of UNCED goals will require the implementation of a new paradigm aimed at greater integration of the highly sectorized approach to solving problems of coastal habitat degradation, marine pollution, and the overexploitation of fisheries than has been practiced in ocean monitoring and management by coastal nations during most of this century. It will also require a working partnership between the developed and developing nations of the world. Such an approach should be based on principles of ecology and sustainable development.

An ecological framework that may be useful in achieving the UNCED objectives is the large marine ecosystem (LME) concept. LMEs are areas which are being subjected to increasing stress from growing 
exploitation of fish and other renewable resources, coastal zone damage, habitat losses, river basin runoff, dumping of urban wastes, and fallout from aerosol contaminants. The LMEs are regions of ocean space encompassing coastal areas from river basins and estuaries on out to the seaward boundary of continental shelves and the seaward margins of coastal current systems. They are relatively large regions on the order of $200000 \mathrm{~km}^{2}$ or larger, characterized by distinct bathymetry, hydrography, productivity, and trophically dependent populations. The theory, measurement, and modelling relevant to monitoring the changing states of LMEs are imbedded in reports on ecosystems with multiple steady states, and on the pattern formation and spatial diffusion within ecosystems (Holling 1973, 1986, 1993, Pimm 1984, AAAS 1986, 1989, 1990, 1991, 1993, Beddington 1986, Mangel 1991, Levin 1993).
From the ecological perspective, the concept that critical processes controlling the structure and function of biological communities can best be addressed on a regional basis (Ricklefs 1987) has been applied to ocean space in the utilization of marine ecosystems as distinct global units for marine research, monitoring, and management. The concept of monitoring and managing renewable resources from an LME perspective has been the topic of a series of national and international symposia and workshops initiated in 1984 and continuing through 1993, wherein the geographic extent of each region is defined on the basis of ecological criteria (Table 1). The spawning and feeding migrations of fish communities within the LMEs have evolved in response to the distinct bathymetry, hydrography, productivity, and trophodynamics of the system. As the spatial dimension of biological and physical processes directly influencing the success of

Table 1. List of 29 large marine ecosystems and subsystems for which syntheses relating to principal, secondary, or tertiary driving forces controlling variability in biomass yields have been completed by February 1993

\begin{tabular}{|c|c|c|}
\hline Large marine ecosystem & Source & Authors \\
\hline U.S. Northeast Continental Shelf & $\begin{array}{l}\text { AAAS (1986) } \\
\text { AAAS (1991) }\end{array}$ & $\begin{array}{l}\text { M. Sissenwine } \\
\text { P. Falkowski }\end{array}$ \\
\hline U.S. Southeast Continental Shelf & AAAS (1991) & J. Yoder \\
\hline Gulf of Mexico & $\begin{array}{l}\text { AAAS (1989) } \\
\text { AAAS (1991) }\end{array}$ & $\begin{array}{l}\text { W. J. Richards \& M. F. McGowan } \\
\text { B. E. Brown et al. }\end{array}$ \\
\hline California Current & $\begin{array}{l}\text { AAAS }(1986) \\
\text { AAAS }(1991) \\
\text { AAAS }(1993)\end{array}$ & $\begin{array}{l}\text { A. MacCall } \\
\text { M. Mullin } \\
\text { D. Bottom }\end{array}$ \\
\hline $\begin{array}{l}\text { Eastern Bering Shelf } \\
\text { West Greenland Shelf } \\
\text { Norwegian Sea } \\
\text { Barents Sea }\end{array}$ & $\begin{array}{l}\text { AAAS }(1986) \\
\text { AAAS }(1990) \\
\text { AAAS }(1990) \\
\text { AAAS }(1989) \\
\text { AAAS }(1991)\end{array}$ & $\begin{array}{l}\text { L. Incze \& J. D. Schumacher } \\
\text { H. Hovgaard \& E. Buch } \\
\text { B. Ellertsen et al. } \\
\text { H. R. Skjoldal \& F. Rey } \\
\text { V. Borisov }\end{array}$ \\
\hline North Sea & AAAS (1986) & N. Daan \\
\hline Baltic Sea & AAAS (1986) & G. Kullenberg \\
\hline Iberian Coastal & AAAS (1989) & T. Wyatt \& G. Perez-Gandaras \\
\hline Mediterranean - Adriatic Sea & AAAS (1993) & G. Bombace \\
\hline Canary Current & AAAS (1993) & C. Bas \\
\hline Gulf of Guinea & AAAS (1993) & D. Binet \& E. Marchal \\
\hline Benguela Current & AAAS (1989) & R. J. M. Crawford et al. \\
\hline Patagonian Shelf & AAAS (1993) & A. Bakun \\
\hline Caribbean Sea & AAAS (1990) & W. J. Richards \& J. A. Bohnsack \\
\hline South China Sea - Gulf of Thailand & AAAS (1989) & T. Piyakarnchana \\
\hline Yellow Sea & AAAS (1989) & Q. Tang \\
\hline Sea of Okhotsk & AAAS (1993) & V. V. Kusnetsov \\
\hline Humboldt Current & AAAS (1993) & J. Alheit \& P. Bernal \\
\hline Indonesia Seas - Banda Sea & AAAS (1990) & J. J. Zijlstra \& M. A. Baars \\
\hline Bay of Bengal & AAAS (1993) & S. N. Dwivedi \\
\hline Antarctic Marine & AAAS $(1986,1993)$ & R. T. Scully et al. \\
\hline Weddell Sea & AAAS $(1990)$ & G. Hempel \\
\hline Kuroshio Current & AAAS (1989) & M. Terazaki \\
\hline Oyashio Current & AAAS (1989) & T. Minoda \\
\hline Great Barrier Reef & AAAS (1989) & R. H. Bradbury \& C. N. Mundy \\
\hline & AAAS (1993) & G. Kelleher \\
\hline South China Sea & AAAS (1993) & D. Pauly \& V. Christensen \\
\hline
\end{tabular}


population renewals within the regions under consideration are large, the term 'large marine ecosystem' is used to characterize them. Several LMEs are semienclosed, including the Black, Baltic, Mediterranean, and Caribbean seas. Within the extent of LMEs, domains or subsystems can be characterized. For example the Adriatic Sea is a subsystem of the Mediterranean Sea LME. In other LMEs, geographic limits are defined by the scope of continental shelves. Among these are the U.S. Northeast Continental Shelf and its 4 subsystems - the Gulf of Maine, Georges Bank, Southern New England, and the Mid-Atlantic Bight (Sherman et al. 1988) - the Icelandic Shelf and the Northwestern Australian Shelf. For LMEs with narrow shelf areas and well-defined currents, the seaward boundaries are limited to the areas affected by coastal currents, rather than relying on the 200 mile Exclusive Economic Zone (EEZ) limits. Among the coastal current LMEs are the Humboldt, California, Canary, Kuroshio, and Benguela currents. It is the coastal ecosystems adjacent to the land masses that are being stressed from habitat degradation, pollution, and overexploitation of marine resources. Nearly $95 \%$ of the usable annual global biomass yield of fish and other living marine resources is produced in 49 LMEs identified within, and in some cases extending beyond, the boundaries of the EEZs of coastal nations located around the margins of the ocean basins (Fig. 1).

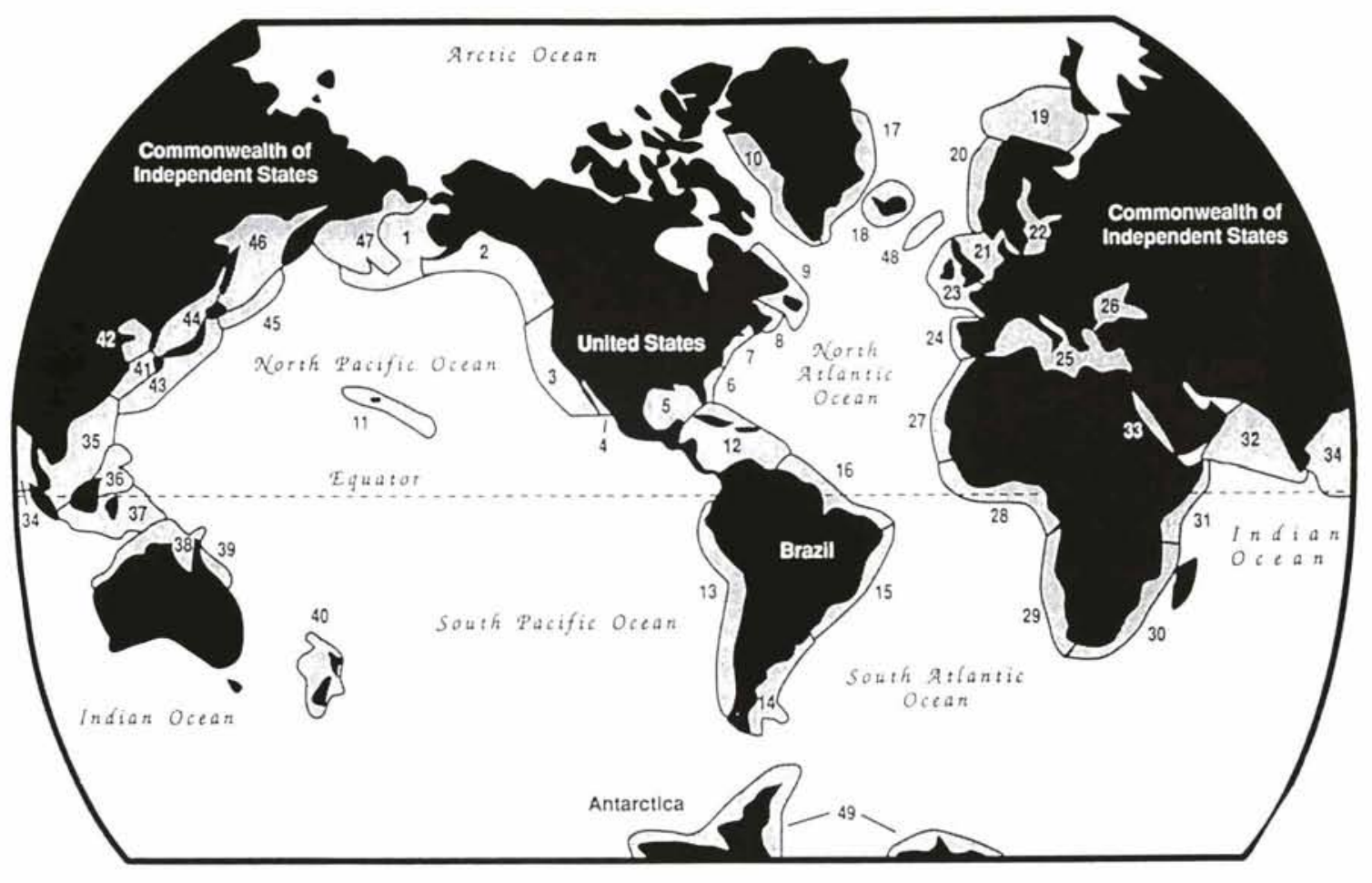

Fig. 1. Boundaries of 49 large marine ecosystems

1. Eastern Bering Sea

2. Gulf of Alaska

3. California Current

4. Gulf of California

5. Gulf of Mexico

6. Southeast U.S. Continental Shelf

7. Northeast U.S. Continental Shelf

8. Scotian Shelf

9. Newfoundland Shelf

10. West Greenland Shelf

11. Insular Pacific - Hawaiian

12. Caribbean Sea

13. Humboldt Current

14. Patagonian Shelf

15. Brazil Current

16. Northeast Brazil Shelf

17. East Greenland Shelf
18. Iceland Shelf

19. Barents Sea

20. Norwegian Shelf

21. North Sea

22. Baltic Sea

23. Celtic-Biscay Shelf

24. Iberian Coastal

25. Mediterranean Sea

26. Black Sea

27. Canary Current

28. Guinea Current

29. Benguela Current

30. Agulhas Current

31. Somali Coastal Current

32. Arabian Sea

33. Red Sea

34. Bay of Bengal
35. South China Sea

36. Sulu-Celebes Seas

37. Indonesian Seas

38. Northern Australian Shelf

39. Great Barrier Reef

40. New Zealand Shelf

41. East China Sea

42. Yellow Sea

43. Kuroshio Current

44. Sea of Japan

45. Oyashio Current

46. Sea of Okhotsk

47. West Bering Sea

48. Faroe Plateau

49. Antarctic 
Levels of primary production are persistently higher around the margins of the ocean basins than for the open-ocean pelagic areas of the globe. It is within these coastal ocean areas that pollution has its greatest impact on natural productivity cycles, including eutrophication from high nitrogen and phosphorus effluent from estuaries. The presence of toxins in poorly treated sewage discharge, harmful algal blooms, and loss of wetland nursery areas to coastal development are also ecosystem-level problems that need to be addressed (GESAMP 1990). Within several of the coastal LMEs, overfishing has caused biomass flips among the dominant pelagic components of fish communities resulting in multimillion metric ton losses in potential biomass yield (Fogarty et al. 1991). The biomass flip, wherein a dominant species rapidly drops to a low level to be succeeded by another species, can generate cascading effects among other important components of the ecosystem, including marine birds (Powers \& Brown 1987), marine mammals, and zooplankton (Overholtz \& Nicolas 1979, Payne et al. 1990). Recent studies implicate climate and natural environmental changes as prime driving forces of variability in fish population levels (Kawasaki et al. 1991, Alheit \& Bernal 1993, Bakun 1993). The growing awareness that biomass yields are being influenced by multiple driving forces in marine ecosystems around the globe has accelerated efforts to broaden monitoring strategies to encompass food chain dynamics and the effects of environmental perturbations and pollution on living marine resources from an ecosystem perspective.

Consideration should be given to the use of standard and intercalibrated protocols for measuring changing ecological states of the watersheds, bays, estuaries, and coastal water of LMEs. Long-term historical time series data on living marine resources (some up to $40 \mathrm{yr})$, coupled with measured or inferred long-term pollutant loading histories, have proven useful for relating the results of intensive monitoring to the quantification of 'cause and effect' mechanisms affecting the changing ecological states of LMEs. Temporal and spatial scales influencing biological production and changing ecological states in marine ecosystems have been the topic of a number of theoretical and empirical studies. The selection of scale in any study is related to the processes under investigation. An excellent treatment of this topic can be found in Steele (1988). Steele indicates that in relation to general ecology of the sea, the best known work in marine population dynamics includes studies by Schaefer (1954), and Beverton \& Holt (1957), following the earlier pioneering approach of Lindemann (1942). However, as noted by Steele (1988), this array of models is unsuitable for consideration of temporal or spatial variability in the ocean. A heuristic projection

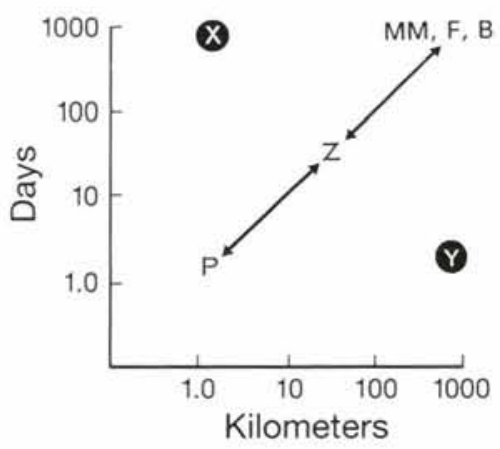

Fig. 2. A simple set of scale relations for the food web. (P) Phytoplankton, (Z) zooplankton, (F) fish, (MM) marine mammals, (B) birds. Two physical processes are indicated by (X) predictable fronts with small cross-front dimensions, and (Y) weather events occurring over relatively large scales. (Adapted from Steele 1988)

was produced by Steele (1988) to illustrate scales of importance in monitoring pelagic components of the ecosystem including phytoplankton, zooplankton, fish, frontal processes, and short-term but large-area episodic effects (Fig. 2). The LME approach defines a spatial domain based on ecological principles and, thereby, provides a basis for focused temporal and spatial scientific research and monitoring efforts in support of management aimed at the long-term productivity and sustainability of marine habitats and resources.

\section{PERTURBATIONS AND DRIVING FORCES IN LARGE MARINE ECOSYSTEMS}

Among the marine resources at risk from global climate change and human intervention of natural productivity cycles are the fish components of coastal LMEs. Increasing attention has been focused over the past few years on synthesizing available biological and environmental information influencing the natural productivity of the fishery biomass within LMEs in an effort to identify the primary, secondary and, where important, the tertiary driving forces causing major shifts in species composition.

Through the mid 1970 s, the predictions of the levels of biomass yields for different regions of the world ocean were open to disagreement (Ryther 1969, Alverson et al. 1970, Lasker 1988). It is clear that 'experts' have been off the mark in earlier estimates of global yield of fisheries biomass. Projections given in U.S. Council on Environmental Quality (1980) indicated that the world annual yield was expected to rise little, if at all, by the year 2000 from the 60 million metric tons (mmt) reached in the 1970 s. In contrast, estimates given in Wise (1984) argue for an annual yield of 100 to 
$120 \mathrm{mmt}$ by the year 2000 . The upward trend of the past 2 decades reached the 1989 level of marine global fishery yields of $86.5 \mathrm{mmt}$ (FAO 1992), and has since leveled off. The lack of a clear definition of actual and/or potential global yield is not unexpected, given the limited efforts presently underway to improve the global information base on living marine resource yields. A milestone in fishery science was achieved in 1975 with the convening of a symposium by the ICES that focused on changes in the fish stocks of the North Sea and their causes. The symposium, which dealt with the North Sea as an ecosystem, following the lead of Steele (1974), Cushing (1975), Andersen \& Ursin (1977), and others, was prompted by a rather dramatic shift in the finfish community of the North Sea from a balance between pelagic and demersal finfish prior to 1960 to demersal domination from the mid 1960s through the mid 1970s. Although no consensus on cause and effect was reached by the participants, it was suggested by the convener (Hempel 1978) that the previous studies of $7 \frac{1}{2}$ decades may have been too narrowly focused, and that future studies should take into consideration fish stocks, their competitors, predators and prey, and interactions of the fish stocks with their environments, the fisheries, habitat change, and pollution from an ecosystems perspective.

The LMEs that together produce approximately $95 \%$ of the annual global fisheries biomass yield are listed in Table 2. Although the United Nations Food and Agriculture Organization (FAO) world fishery statistics have shown an upward trend in annual biomass yields for the past 3 decades (1960 through 1990), it is largely the clupeoids that are increasing in abundance (FAO 1992). A large number of stocks have been and continue to be fished at levels above long-term sustainability. The variations in abundance levels among the species constituting the annual global biomass yields are indicative of changing regional ecosystem states caused by natural environmental perturbations, overexploitation, and pollution. Although the spatial dimensions of LMEs preclude a strictly controlled experimental approach to their study, they are perfectly amenable to the comparative method of science as described by Bakun (1993).

A deliberate effort was initiated in 1984 to convene a series of symposia and conferences to provide an international forum for bringing forward the results of multidisciplinary syntheses of available information on the principal driving forces of change in biomass yields for selected LMEs. Since 1984, case studies investigating the major causes of large-scale perturbations in biomass yields of 29 LMEs have been completed (Table 1). The principal driving forces for biomass changes vary among ecosystems. Results of the case studies, including generalizations on principal, secondary, and tertiary driving forces, are given in 5 volumes published in cooperation with the American Association for the Advancement of Science (AAAS). A list of the principal investigators and contributors to the volumes is given in Table 1. In some systems, natural environmental perturbation is the principal driver of change in fisheries biomass production (e.g. Oyashio, Kuroshio, Benguela, and Humboldt Current Ecosystems). In several shelf ecosystems, overexploitation is the principal source of changes in the structure of the fish community and biomass yields (e.g. Gulf of Thailand, U.S. Northeast Continental Shelf, Yellow Sea Ecosystems). And in other ecosystems, the principal cause for structural change in the fish community is the effect of coastal eutrophication (e.g. Black Sea, northwest Adriatic Sea Ecosystems). For several other systems, the evidence for causes of observed changes in biomass yield are inconclusive (e.g. Gulf of Mexico, East Bering Sea, North Sea Ecosystems).

Changes in the ocean climate of the northern North Atlantic during the late 1960 s and early 1970 s have been considered by some marine scientists as the dominant cause of change in the food chain structure and biomass yields of at least 3 northern North Atlantic LMEs. Large-scale declines in the population levels of important fish stocks (e.g. capelin, cod) within the Norwegian Sea, Barents Sea, and West Greenland Sea ecosystems have been observed. In the West Greenland Sea Ecosystem, cod stocks were displaced southward since 1980 , attended by a decrease in their average size and abundance. Biomass yields declined from about 300000 metric tons (mt) per year in the mid 1960 s to less than $15000 \mathrm{mt}$ in 1985. Both changes appear to have been due to shortterm cooling that influenced stability of water masses and dynamics of the plankton community, and adversely affected the growth and survival of early developmental stages of cod, resulting in a reduction in recruitment. Observations since the 1920s have shown that catches of cod are correlated with temperature - increasing during warm periods and declining during cool periods. The effects of fishing mortality on the decline of the cod are secondary to the major influence of climatic conditions over the North Atlantic (Hovgaard \& Buch 1990).

To the east, changes in the temperature structure of the Norwegian Sea Ecosystem also appear to be the major driving force controlling the recruitment of the commercially important cod stocks (Ellertsen et al. 1990).

The changes in biomass yields of the Barents Sea Ecosystem have been attributed primarily to changes in hydrographic conditions and secondarily to excessive fishing mortality. The average annual biomass yield (fish, crustaceans, molluscs, algae) of the eco- 
Table 2. Contributions to global fisheries yield by country, and large marine ecosystem (LME), representing $95 \%$ of the annual global catch in 1990

\begin{tabular}{|c|c|c|c|}
\hline Country & $\begin{array}{l}\text { Percentage of } \\
\text { world marine } \\
\text { nominal catch }\end{array}$ & LMEs producing annual biomass yield & $\begin{array}{l}\text { Cumulative } \\
\text { percentages }\end{array}$ \\
\hline Japan & 12.25 & $\begin{array}{l}\text { Oyashio Current, Kuroshio Current, Sea of Okhotsk, } \\
\text { Sea of Japan, Yellow Sea, East China Sea, } \\
\text { W. Bering Sea, E. Bering Sea, Scotia Sea }\end{array}$ & \\
\hline USSR & 11.37 & $\begin{array}{l}\text { Sea of Okhotsk, Barents Sea, Norwegian Shelf, W. Bering Sea, } \\
\text { E. Bering Sea, Scotia Sea }\end{array}$ & \\
\hline China & 8.28 & W. Bering Sea, Yellow Sea, E. China Sea, S. China Sea & \\
\hline Peru & 8.27 & Humboldt Current & \\
\hline USA & 6.76 & $\begin{array}{l}\text { Northeast U.S. Shelf, Southeast U.S. Shelf, Gulf of Mexico, } \\
\text { California Current, Gulf of Alaska, E. Bering Sea }\end{array}$ & \\
\hline Chile & 5.98 & Humboldt Current & 52.91 \\
\hline Korea Republic & $3.28 \mathrm{~F}^{\mathrm{b}}$ & Yellow Sea, Sea of Japan, E. China Sea, Kuroshio Current & \\
\hline Thailand & $2.96 \mathrm{~F}$ & South China Sea, Indonesian Seas & \\
\hline India & 2.78 & Bay of Bengal, Arabian Sea & \\
\hline Indonesia & 2.76 & Indonesian Seas & \\
\hline Norway & 2.11 & Norwegian Shelf, Barents Sea & \\
\hline Korea D. P. Rep. & $1.98 \mathrm{~F}$ & Sea of Japan, Yellow Sea & \\
\hline Philippines & 1.96 & S. China Sea, Sulu-Celebes Sea & \\
\hline Canada & 1.90 & Scotian Shelf, Northeast U.S. Shelf, Newfoundland Shelf & \\
\hline Iceland & 1.82 & Icelandic Shelf & \\
\hline Denmark & 2.07 & Baltic Sea, North Sea & 76.25 \\
\hline Spain & 1.73 & Iberian Coastal Current, Canary Current & \\
\hline Mexico & 1.46 & Gulf of California, Gulf of Mexico, California Current & \\
\hline France & $1.03 \mathrm{~F}$ & North Sea, Biscay-Celtic Shelf, Mediterranean Sea & 80.47 \\
\hline Viet Nam & 0.74 & South China Sea & \\
\hline Myanmar & 0.72 & Bay of Bengal, Andaman Sea & \\
\hline Brazil & $0.71 \mathrm{~F}$ & Patagonian Shelf, Brazil Current & \\
\hline Malaysia & $0.71 \mathrm{~F}$ & Gulf of Thailand, Andaman Sea, Indonesian Seas, S. China Sea & \\
\hline UK (Scotland) & 0.70 & North Sea & \\
\hline New Zealand & 0.68 & New Zealand Shelf Ecosystem & \\
\hline Morocco & 0.68 & Canary Current & \\
\hline Argentina & 0.66 & Patagonian Shelf & \\
\hline Italy & 0.57 & Mediterranean Sea & \\
\hline The Netherlands & 0.52 & North Sea & \\
\hline Poland & 0.52 & Baltic Sea & \\
\hline Ecuador & 0.47 & Humboldt Current & \\
\hline Pakistan & 0.44 & Bay of Bengal & \\
\hline Turkey & $\begin{array}{l}0.41 \\
0.41\end{array}$ & $\begin{array}{l}\text { Black Sea, Mediterranean Sea } \\
\text { Baltic Sea }\end{array}$ & \\
\hline $\begin{array}{l}\text { Germany } \\
\text { Ghana }\end{array}$ & $\begin{array}{l}0.41 \\
0.40\end{array}$ & $\begin{array}{l}\text { Baltic Sea } \\
\text { Gulf of Guinea }\end{array}$ & \\
\hline Portugal & 0.39 & Iberian Shelf, Canary Current & 90.20 \\
\hline Venezuela & 0.38 & Caribbean Sea & \\
\hline Namibia & 0.35 & Benguela Current & \\
\hline Faeroe Islands & 0.34 & Faeroe Plateau & \\
\hline Senegal & 0.34 & Gulf of Guinea, Canary Current & \\
\hline Sweden & 0.31 & Baltic Sea & \\
\hline Bangladesh & 0.31 & Bay of Bengal & \\
\hline
\end{tabular}


Table 2 (continued)

\begin{tabular}{|lll|}
\hline Country & $\begin{array}{c}\text { Percentage of } \\
\text { world marine } \\
\text { nominal catch }\end{array}$ & \multicolumn{1}{c|}{ LMEs producing annual biomass yield } \\
\hline Ireland & 0.28 & $\begin{array}{c}\text { Cumulative } \\
\text { percentages }\end{array}$ \\
Hong Kong & 0.28 & Biscay-Celtic Shelf \\
Nigeria & 0.26 & Gulf of Guinea \\
Australia & 0.25 & N. Australian Shelf, Great Barrier Reef \\
Iran & $0.24 \mathrm{~F}$ & Arabian Sea \\
UK (England, Wales) & 0.21 & North Sea \\
Cuba & 0.20 & Caribbean Sea \\
Panama & 0.19 & California Current, Caribbean Sea \\
Greenland & 0.17 & East Greenland Shelf, West Greenland Shelf \\
Sri Lanka & 0.19 & Bay of Bengal \\
Greece & 0.16 & Mediterranean Sea \\
Oman & 0.15 & Arabian Sea \\
Angola & 0.12 & Guinea Current, Angola Basin \\
United Arab Em. & 0.11 & Arabian Sea \\
a Percentages based on fish catch statistics from FAO (1992). Some fraction of the catch made by fishing operations of long- \\
distance trawlers may actually be caught in other LMEs \\
bF Percentage calculated using FAO estimate from available sources of information \\
\hline
\end{tabular}

system in the 1970 s was about $2 \mathrm{mmt}$. However, by the 1980s annual yields declined to approximately $350000 \mathrm{mt}$ (Borisov 1991). Strong year-classes of Barents Sea herring, cod, and haddock appear related to warming phases of short-term climatic fluctuations on the order of $4 \mathrm{yr}$ (Blindheim \& Skjoldal 1993).

In the North Sea Ecosystem, important species 'flipped' from a dominant to a subordinate position over the decade of the 1960 s. The finfish stocks of the North Sea Ecosystem have been subjected to intensive fishing mortality, resulting in a decrease in pelagic herring and mackerel yields from 5 to $1.7 \mathrm{mmt}$, whereas small, fast-growing and commercially less desirable sand lance (also called sand eel), Norway pout, and sprat yields increased by $1.5 \mathrm{mmt}$ along with an approximate $36 \%$ increase in gadoid yields. The causes for the biomass flips are not well understood. Several arguments suggest that the 'flip' is caused by changing oceanographic conditions as the principal driving force. Other explanations support overexploitation as the major cause. However, none of the arguments can be considered more than speculative at this time, pending rigorous analysis of more recent information (Hempel 1978, Postma \& Zijlstra 1988).

Further to the south in the Atlantic are the Iberian Shelf and Benguela Current Ecosystems, where the abundance of important fishery resources also seems to be related to climate-induced changes in the physical dynamics within each system. The alternation in abundance levels of horse mackerel and sardine within the Iberian Coastal Ecosystem is attributed to changes in natural environmental perturbation of its thermal structure rather than to any density-dependent interaction among the 2 species (Wyatt \& Perez-Gandaras 1989).

Similarly, in the Benguela Current Ecosystem of the southwest coast of Africa, the long-term fluctuations in the abundance levels of pilchard, horse mackerel, hakes, and anchovy are attributed to changes in the oceanographic regime. The Benguela LME is bounded by warm water regimes at both the equatorward and polarward extremities. Cold, nutrient-rich water upwells intensely in the central section and less intensely and seasonally in the northern and southern areas. In general, warmer environmental conditions favor the epipelagic species, and cooler conditions favor the demersal species. The environment has been a principal driving force for large-scale shifts in abundance among the fish species (Shelton et al. 1985). The effects of the fisheries on changes in species abundance are secondary. Changes in abundance of pilchard stocks have led to detectable effects in the abundance level of dependent predator species, particularly marine bird populations, and to flips in dominant species such as anchovy replacing pilchard (Crawford et al. 1989).

In the Pacific, the greatest increases in biomass yields have been reported at the area of confluence between the Oyashio and Kuroshio Current Ecosystems off Japan (Minoda 1989, Terazaki 1989) and in 
the Humboldt Current Ecosystem off Chile. In the Oyashio and Kuroshio Current Ecosystems the yield of Japanese sardines increased from less than $0.5 \mathrm{mmt}$ in 1975 to just over $4 \mathrm{mmt}$ in 1984 . The yield of the Chilean sardine in the Humboldt Current Ecosystem also increased from about $500000 \mathrm{mt}$ in 1974 to 4.3 $\mathrm{mmt}$ in 1986. The increased yields have been attributed to density-independent processes involving an increase in lower food chain productivity, made possible by coastward shifts in the boundary areas of the Oyashio and Kuroshio systems and water mass shifts in the Humboldt Current Ecosystem. The effects of fishing on the sardines in both areas were of secondary importance compared to the enhanced productivity of the phytoplankton and zooplankton components of the ecosystems that provided an improved environment for growth and recruitment. Studies are underway to determine the extent of the teleconnection between the Pacific-wide El Niño events of the past decade and: (1) the multimillion metric ton increases in yields of sardines occurring nearly simultaneously in the northern and southern hemispheres, and (2) the dramatic decline in the biomass yields of anchovy in the northern areas of the Humboldt Current Ecosystem in the early 1970 s from about $12 \mathrm{mmt}$ in 1970 to less than $2 \mathrm{mmt}$ by 1976 (Canon 1986) and the increasing yields of pelagic fish in the 1980s (Alheit \& Bernal 1993) (Fig. 3).

Although less dramatic, the long-term shifts in abundance levels of both sardines and anchovies within the California Current Ecosystem are considered the result primarily of natural environmental change and secondarily of intensive fishing, rather than of any densitydependent competition between the 2 species (MacCall 1986).

To the north and west of Australia lies the relatively pristine Banda Sea Ecosystem, where no large-scale fisheries are presently conducted. The ecosystem is

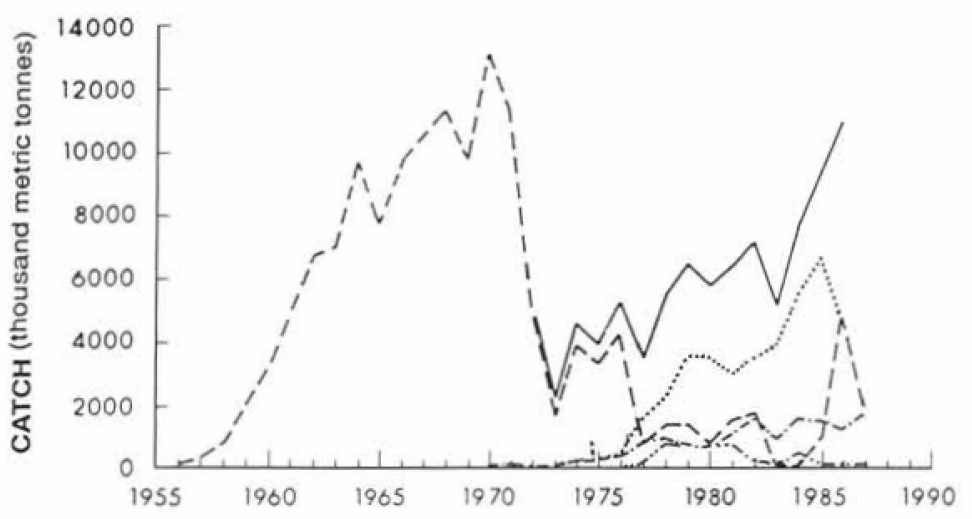

Fig. 3. Catches of pelagic fish in the Humboldt Current Ecosystem. Pelagics, total (-); anchovy (----); sardine $(\cdots \cdot)$; horse mackerel (-.--); mackerel (-....- -). (From Alheit \& Bernal 1993) under the influence of monsoon-induced seasonal periods of large-scale upwelling and downwelling. Biological feedback to these environmental signals is reflected in the changes in phytoplankton, mesozooplankton, micronekton, and fish. During upwelling events, productivity of the ecosystem is enhanced by a factor of 2 to 3 . The biomass of pelagic fish resources is also higher during the upwelling period. The fish biomass of the ecosystem is estimated at between $600000 \mathrm{mt}$ to $900000 \mathrm{mt}$ in the peak upwelling season (August), and $150000 \mathrm{mt}$ to $250000 \mathrm{mt}$ in the downwelling period (February). The estimated sustained annual biomass yield of the ecosystem is approximately $30000 \mathrm{mt}$ of pelagic fish (Zijlstra \& Baars 1990).

Changes in biomass yields of 2 other Pacific Rim LMEs have been the result of overexploitation. The introduction of highly efficient modern trawlers to the Gulf of Thailand Ecosystem, in an effort to increase fishing efficiencies, led to excessive fishing mortality and a marked reduction in annual yields of biomass of fish for human consumption between 1977 and 1982.

Intensive fishery effort resulted in the depletion of the demersal fish stocks and dramatic reductions in the biomass yields of the Yellow Sea Ecosystem. Between 1958 and 1968 fisheries yields declined from $180000 \mathrm{mt}$ to less than $10000 \mathrm{mt}$. The fishery then shifted to harvesting pelagic stocks reaching a level of $200000 \mathrm{mt}$ in 1972 , followed by a reduction to less than $20000 \mathrm{mt}$ in 1981. The fisheries of the Yellow Sea in 1982 shifted principally to anchovy and sardine with a total annual yield of all species $40 \%$ lower than the 1958 level. The demersal fishery remains in a depleted state (Tang 1989, 1993) (Fig. 4). In several near-coastal areas of the northwestern coast, evidence of increasing contaminant loadings has been observed (She 1993, Wei et al. 1993).

The importance of a natural predator driving an ecosystem is evidenced in the large-scale changes in the community structure of the Great Barrier Reef Ecosystem that extends over $230000 \mathrm{~km}^{2}$ of the Queensland continental shelf. The predation by the crown-of-thorns starfish in the 1960s and 1970 s resulted in a shift in the biomass of corals, community structure of the benthos, and a decoupling of energy transfer to several fish stocks (Bradbury \& Mundy 1989 ).

In the enclosed and semi-enclosed marine ecosystems, the effects of pollution in the form of coastal eutrophication attributed to high levels of nitrate and phosphate inputs from population centers have resulted in unusual phytoplankton blooms, oxygen depletion, bio- 


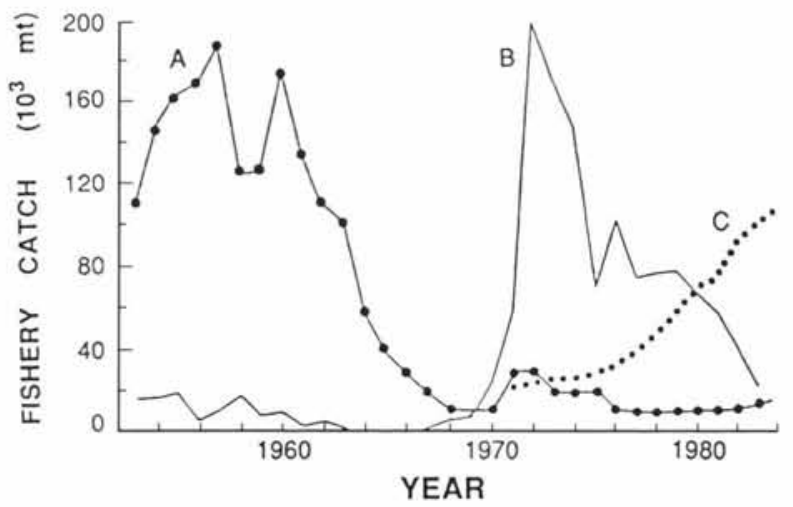

Fig. 4. Annual catch of dominant species [(A) small yellow croaker and hairtail; (B) Pacific herring and Japanese mackerel; (C) Setipinna taty, anchovy and scaled sardine] of the Yellow Sea ecosystem, 1953 through 1984. (From Tang 1989)

toxin generated mortalities, and changes in ecosystem trophodynamics (Smayda 1991). Among the impacted ecosystems are the Black Sea (Mee 1992, Zaitsev 1992, Caddy 1993), Baltic Sea (Kullenberg 1986), and northwest Adriatic Sea (Bombace 1993).

\section{MANAGEMENT AND SUSTAINABILITY CONSIDERATIONS}

Empirical and theoretical aspects of yield models for large marine ecosystems have been reviewed by several ecologists. According to Beddington (1986), Daan (1986), Levin (1990), and Mangel (1991), published dynamic models of marine ecosystems offer little guidance on the detailed behavior of communities. However, these authors concur on the need for covering the common ground between observation and theory by implementing monitoring efforts on the large spatial and long temporal scales (decadal) of 'key' components of the LMEs. The sequence for improving the understanding of the possible mechanisms underlying observed patterns in LMEs is described by Levin (1990) as examination of: (1) statistical analyses of observed distributional patterns of physical and biological variables; (2) construction of competing models of variability and patchiness based on statistical analyses and natural scales of variability of critical processes; (3) evaluation of competing models through experimental and theoretical studies of component systems; and (4) integration of validated component models to provide predictive models for population dynamics and redistribution. The approach suggested by Levin (1990) is consistent with the observation by Mangel (1991) that empirical support for the currently used models of LMEs is relatively weak, and that a new generation of models is needed that serves to enhance the linkage between theory and empirical results.
There is a growing awareness among marine scientists, geographers, economists, government representatives, and lawyers, of the utility of a more holistic ecosystem approach to resource management (Byrne 1986, Christy 1986, Alexander 1989, Belsky 1989, Crawford et al. 1989, Morgan 1989, Prescott 1989). On a global scale the loss of sustained biomass yields from LMEs from mismanagement and overexploitation has not been fully investigated but is likely very large (Gulland 1984). Effective management strategies for LMEs will be contingent on the identification of the major driving forces causing large-scale changes in biomass yields. Management of species responding to strong environmental signals will be enhanced by improving the understanding of the physical factors forcing biological change, thereby enhancing forecasts of El Niño-type events. In other LMEs, where the prime driving force is predation, options can be explored for implementing adaptive management strategies (Collie 1991). Remedial actions are required to ensure that the 'pollution' of the coastal zone of LMEs is reduced and does not become a principal driving force in any LME.

\section{SOCIOECONOMIC COMPONENTS}

A distinguishing feature of the LME approach is its emphasis on practical applications of its scientific findings in managing the LME and on the explicit integration of economic analysis with the scientific research to assure that prospective management measures are cost-effective. Economists and policy analysts will need to work closely with ecologists and other scientists to identify and evaluate management options that are both scientifically credible and economically practical.

The economic and management research will be closely integrated with the science throughout, and is designed intentionally to respond adaptively to enhanced scientific information. This component of the LME approach to marine resources management was developed by James Broadus, Director of the Marine Policy Center, Woods Hole Oceanographic Institution. It consists of 6 interrelated elements:

(1) Human forcing functions. The natural starting point is a generalized characterization of the ways in which human activities affect the natural marine system and the expected sensitivity of these forcing functions to various types and levels of human activity. Population dynamics, coastal development, and landuse practices in the system's drainage basin are clear examples. Work integrating the efforts of natural and social scientists should concentrate further on resolving apparent effects (such as eutrophication-associated red tide events or changing fish population structures) 
that are confounded by cycles or complex dynamics in the natural system itself. Progress is possible, too, in achieving better characterizations of the way in which human forcing is mediated by alternate management options. Emphasis should be on isolating and quantifying those forcing activities (sewage discharge, agricultural runoff, fishing effort) likely to be expressed most prominently in effects on the natural system.

(2) Assessing impacts. Another natural element in the systemic approach is to estimate and even predict the economic impacts of unmanaged degradation in the natural system and, obversely, the expected benefits of management measures. Such assessment is a form of standard benefit-cost analysis, but it requires scientific information to describe the effects of human forcing so they may be quantified in economic terms. Initial analysis should focus on the social and economic sectors likely to experience the largest impacts: fishing, aquaculture, public health, recreation, and tourism.

(3) Feedbacks. Collaborative effort should also be devoted to identifying and estimating the feedbacks of economic impacts into the human forcing function. Extensive coastal eutrophication, for example, associated with coastal development and runoff, might reduce the suitability of coastal areas for aquaculture production and increase its exposure to red tide damage, thereby putting a premium on capture fishery and increasing pressure on wild stocks. Similar feedbacks, both negative and positive, will be addressed and expressed in economic terms for all the major sectors.

(4) Ecosystem service and the value of biodiversity. Special consideration should be given to improved knowledge of how the natural system generates economic values. Many valuable services provided by natural systems are not traded in markets or included in planning evaluations, so extra care must be made to assure that they are not sacrificed through ignorance. The services provided by coastal wetlands as nurseries for fisheries, natural pollution filters, and storm buffers is a well-known example that has particular relevance to coastal reclamation activities. Other examples are more subtle, including the importance of predatorprey relationships and the possibility of losing unrecognized 'keystone' species in a valuable ecosystem. Experience suggests that growing economic values on aesthetic and recreational/tourism amenities may be expected in the LME setting as well. A variety of sources of economic value arising from the natural diversity of the LME should be identified and assessed in regard to existing uses and potential management innovations.

(5) Environmental economics. Many of the elements described in this section comprise topics in 'environmental economics'. Specialists in that field attempt to estimate the economic values (both use and non-use) associated with environmental resources and to identify the conditions associated with their optimal management (to derive the greatest net benefits for society). An important element is the collaboration between scholars from developing nations and those from the developed countries to transfer and adapt to the needs and techniques of environmental economics.

(6) Integrated assessment. The ultimate objective is the integration of all the results achieved above, with scientific characterizations of the LME, into a comprehensive analytic framework (decision support environment) that will permit integrated assessment of human practices, effects, and management options in the region. Such work is at the forefront of recent research on the human dimensions of global environmental change as well as research on human interactions with natural coastal/marine systems.

A systems approach to the management of LMEs is depicted in Table 3 . The LMEs represent the link between local events (e.g. fishing, pollution, environmental disturbance) occurring on the daily-to-seasonal temporal scale and their effects on living marine resources and the more ubiquitous global effects of climate changes on the multidecadal timescale. The regional and temporal focus of season to decade is consistent with the evolved spawning and feeding migrations of the fishes. These migrations are seasonal and occur over hundreds to thousands of kilometers within the unique physical and biological characteristics of the regional LME to which they have adapted. As the fisheries represent most of the usable biomass yield of the LMEs and fish populations consist of several age classes, it follows that measures of variability in growth, recruitment, and mortality should be conducted over multi-year time scales. Similarly, changes in populations of marine mammals and marine bird species will require multiple-year time-series observations. Consideration of the naturally occurring environmental events and the human-induced perturbations, including coastal pollution, affecting demography of the populations within the ecosystem is necessary. Based on scientific inferences of the principal causes of variability in abundance and with due consideration to socioeconomic needs, management options from an ecosystems perspective can be considered for implementation. The final element in the system, with regard to the concept of resource maintenance and sustained yield, is the feedback loop that allows for evaluation of the effects of management actions that consider both fisheries and ecosystem health.

It will be necessary to conduct supportive research on the processes controlling sustained productivity of LMEs. Within several of the LMEs of the United States, including the Northeast Shelf, Gulf of Mexico, California Current, and Eastern Bering Sea, important hypo- 
Table 3. Key spatial and temporal scales and principal elements of a systems approach to the research and management of large marine ecosystems

\begin{tabular}{|c|c|c|c|}
\hline \multicolumn{3}{|c|}{ 1. Spatial-temporal scales } & \\
\hline 1.1 & Global (World Ocean) & Millennia - decadal & Pelagic biogeographic \\
\hline 1.2 & Regional (Exclusive Economic Zones) & Decadal - seasonal & Large marine ecosystems \\
\hline 1.3 & Local & Seasonal - daily & Subsystems \\
\hline \multicolumn{4}{|c|}{ 2. Research elements } \\
\hline 2.1 & Spawning strategies & & \\
\hline 2.2 & Feeding strategies & & \\
\hline 2.3 & Productivity, trophodynamics & & \\
\hline 2.4 & Stock fluctuations/recruitment/mortal & & \\
\hline 2.5 & Natural variability (hydrography, curr & er masses, weather) & \\
\hline 2.6 & $\begin{array}{l}\text { Human perturbations } \\
\text { (fishing, waste disposal, petrogenic hy } \\
\text { aerosol contaminants, eutrophication }\end{array}$ & $\begin{array}{l}\text { on impacts, toxic effects, } \\
\text { ollution effects, viral disease vectors) }\end{array}$ & \\
\hline \multicolumn{4}{|c|}{ 3. Management elements - Options and advice - International, national, local } \\
\hline 3.1 & Bioenvironmental and socioeconomic & & \\
\hline 3.2 & Management to optimize sustainable & yields & \\
\hline 3.3 . & Mitigation of pollution stress; improve & ecosystem 'health' & \\
\hline \multicolumn{4}{|c|}{ 4. Feedback loop } \\
\hline 4.1 & Evaluation of ecosystem 'health' & & \\
\hline 4.2 & Evaluation of fisheries status & & \\
\hline 4.3 & Evaluation of management practices & & \\
\hline
\end{tabular}

theses concerned with the growing impacts of pollution, overexploitation, and environmental changes on sustained biomass yields are under investigation (Table 4). By comparing the results of research among the different systems, it should be possible to accelerate an understanding of how the systems respond and recover from stress. The comparisons should allow for narrowing the context of unresolved problems and capitalizing on research efforts underway in the various ecosystems. Reports describing the effects of biological and physical perturbations on the fisheries biomass yields of 29 large marine ecosystems (Table 1) address questions similar to those posed a few years ago by Beddington (1984):

'There are a number of scientific questions which are central to the rational management of marine communities, but all revolve around the question of sustainability.

'What levels of mortality imposed by a fishery will permit a sustainable yield? Are there levels below which a fish population will not recover? Can judicious manipulation of the catch composition of the fishery alter the potential of the community to produce yields of a particular type, e.g., high value species? Can a community be depleted to a level where its potential for producing a harvestable resource is reduced?
'With the exception of the first question, these questions and others like them are rarely explicitly addressed in the scientific bodies of the various fisheries' organizations. Instead, such bodies concentrate on the estimation of stock abundance and the calculation of allowable catch levels, although often implicit in the advice given by these bodies to management are a set of beliefs about the answers to such questions.'

Given the increasing number of responsibilities of government agencies for (1) managing fisheries, (2) mitigating pollution, (3) reducing environmental stress, and (4) restoring lost habitat, it is not surprising that interest is growing to pursue resource management problems from an ecosystem perspective.

\section{ECOSYSTEM ASSESSMENT AND MONITORING}

In the United States, greater emphasis has been focused over the past decade within the National Marine Fisheries Service of the NOAA, on approaching fisheries research from a regional ecosystem perspective in 7 of U.S. coastal waters LMEs: (1) the Northeast Continental Shelf, (2) the Southeast Continental Shelf, (3) the Gulf of Mexico, (4) the California Current, (5) the Gulf of Alaska, (6) the Eastern 
Table 4. Selected hypotheses concerning variability in biomass yields of large marine ecosystems. Sources are given in Table 1 . (From Sherman 1991)

\begin{tabular}{|c|c|c|}
\hline Ecosystem & Predominant variables & Hypothesis \\
\hline $\begin{array}{l}\text { Oyashio Current } \\
\text { Kuroshio Current } \\
\text { California Current } \\
\text { Humboldt Current } \\
\text { Benguela Current } \\
\text { Iberian Coastal }\end{array}$ & $\begin{array}{l}\text { Density-independent } \\
\text { natural environmental } \\
\text { perturbations }\end{array}$ & $\begin{array}{l}\text { Clupeoid population increases: Predominant variables } \\
\text { influencing changes in biomass of clupeoids are major } \\
\text { increases in water-column productivity resulting from } \\
\text { shifts in the direction and flow velocities of the currents } \\
\text { and changes in upwelling within the ecosystem }\end{array}$ \\
\hline $\begin{array}{l}\text { Yellow Sea } \\
\text { U.S. Northeast } \\
\text { Continental Shelf } \\
\text { Gulf of Thailand }\end{array}$ & $\begin{array}{l}\text { Density-dependent } \\
\text { predation }\end{array}$ & $\begin{array}{l}\text { Declines in fish stocks: Precipitous decline in biomass of fish } \\
\text { stocks is the result of excessive fishing mortality, reducing the } \\
\text { probability of reproductive success. Losses in biomass are } \\
\text { attributed to excesses of human predation expressed as } \\
\text { overfishing }\end{array}$ \\
\hline Great Barrier Reef & $\begin{array}{l}\text { Density-dependent } \\
\text { predation }\end{array}$ & $\begin{array}{l}\text { Change in ecosystem structure: The extreme predation } \\
\text { pressure of crown-of-thorns starfish has disrupted normal } \\
\text { food chain linkage between benthic primary production and } \\
\text { the fish component of the reef ecosystem }\end{array}$ \\
\hline $\begin{array}{l}\text { West Greenland Shelf } \\
\text { Barents Sea } \\
\text { Norwegian Sea }\end{array}$ & $\begin{array}{l}\text { Density-independent } \\
\text { natural environmental } \\
\text { perturbations }\end{array}$ & $\begin{array}{l}\text { Shifts in abundance of fish stock biomass: Major shifts in } \\
\text { the levels of fish stock biomass within the ecosystems are } \\
\text { attributed to large-scale environmental changes in water } \\
\text { movements and temperature structure }\end{array}$ \\
\hline Baltic Sea & $\begin{array}{l}\text { Density-independent } \\
\text { pollution }\end{array}$ & $\begin{array}{l}\text { Changes in ecosystem productivity levels: The apparent } \\
\text { increases in productivity levels are attributed to the effects } \\
\text { of nitrate enrichment resulting from elevated levels of } \\
\text { agricultural contaminant inputs from the bordering land masses }\end{array}$ \\
\hline \multirow[t]{2}{*}{ Antarctic Marine } & $\begin{array}{l}\text { Density-dependent } \\
\text { perturbations }\end{array}$ & $\begin{array}{l}\text { Status of krill stocks: Annual natural production cycle of krill is } \\
\text { in balance with food requirements of dependent predator popula- } \\
\text { tions. Surplus production is available to support economically } \\
\text { significant yields, but sustainable level of fishing effort is unknown }\end{array}$ \\
\hline & $\begin{array}{l}\text { Density-independent } \\
\text { natural environmental } \\
\text { perturbations }\end{array}$ & $\begin{array}{l}\text { Shifts in abundance in krill biomass: Major shifts in abundance } \\
\text { levels of krill biomass within the ecosystem are attributed to } \\
\text { large-scale changes in water movements and productivity }\end{array}$ \\
\hline
\end{tabular}

Bering Sea, and (7) the Insular Pacific including the Hawailan Islands. These ecosystems, in 1991, yielded $4.3 \mathrm{mmt}$ of fisheries biomass valued at approximately $\$ 16.5$ billion to the economy of the United States.

The sampling programs providing the biomass assessments within the LMEs have been described in Folio Map 7 produced by the Office of Oceanography and Marine Assessment of NOAA's National Ocean Service. The map depicts the 7 ecosystems under investigation (Fig. 5). Sampling programs supporting biomass estimates in the LMEs are designed to: (1) provide detailed statistical analyses of fish and invertebrate populations constituting the principal yield species of biomass, (2) monitor changes in the principal populations and their environments, and (3) estimate future trends in biomass yields. The information obtained by these programs provides managers with a more complete understanding of the dynamics of marine ecosystems and how these dynamics affect harvestable stocks. Additionally, by tracking components of the ecosystems, these programs can detect changes, natural or human-induced, and warn of events with possible economic repercussions. Although sampling schemes and efforts vary among programs (depending on habitats, species present, and specific regional concerns), they generally involve systematic collection and analysis of catch-statistics and extensive collaborative efforts with other agencies and with academic institutions in the use of NOAA vessels for fisheries-independent bottom and midwater trawl surveys for adults and juveniles; ichthyoplankton surveys for larvae and eggs; measurements of zooplankton standing stock, primary productivity, nutrient concentrations, and important physical parameters (e.g. water temperature, salinity, density, current velocity and direction, air temperature, cloud cover, light conditions); and measurements of contaminants and their effects on living marine resources and coastal eco- 


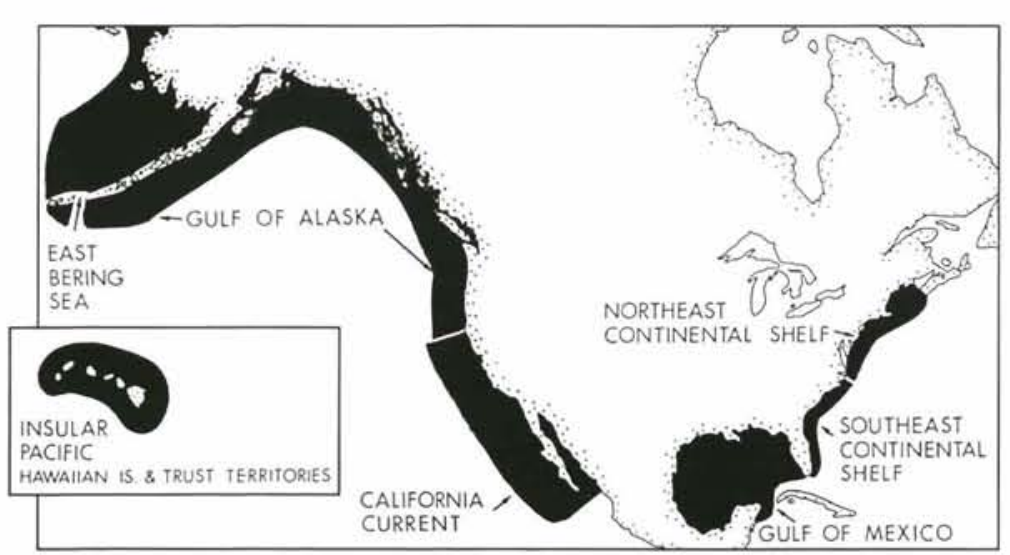

Fig. 5. Large marine ecosystems under investigation by the National Marine Fisheries Service of the National Oceanic and Atmospheric Administration/ NOAA. [This figure is a modified version of Folio Map No. 7 in U.S. Dept of Commerce (1988)]

systems. At the shoreward margin of the LMEs, monitoring efforts include the use of mussels, fish, and other biological indicator species to measure pollution effects as part of NOAA's Status and Trends Program, including the bivalve monitoring strategy of 'MusselWatch' and pathobiological examination of fish (Goldberg 1976, Farrington et al. 1983, ICES 1988, O'Connor \& Ehler 1991). The pilot Environmental Monitoring Assessment Program (EMAP) of the Environmental Protection Agency (EPA) focused on the estuarine and nearshore monitoring of contaminants in the water column, substrate, and selected groups of organisms, will be extended to more open waters of LMEs in cooperation with NOAA during 1994. An important component of the associated research to support the monitoring is the definition of routes of exposure to toxic contaminants of selected finfish and shellfish and the assessment exposure to toxic chemicals by several life history stages. The routes of bioaccumulation and trophic transfer of contaminants is being assessed and critical life history stages and selected food-chain organisms are examined for a variety of parameters that indicate exposure to, and effects of, contaminants. Contaminant-related effects measured include diseases, impaired reproductive capacity, and impaired growth. Many of these effects can be caused by direct exposure to contaminants, or by indirect effects, such as those resulting from alterations in prey organisms. The research support program for assessing chemical contaminant exposure and effects in fishing resources and food-chain organisms consists of a suite of parameters, including biochemical responses that are clearly linked to contaminant exposure coupled with measurements of organ disease and reproductive status that have been used in previous studies to establish links between exposure and effects. The specific suite of parameters measured will cover the same general responses and thus allow comparable assessment of the physiological status of each species sampled as it relates to chemical contaminant exposure and effects at the individual and population level.

A monitoring strategy for measuring the changing states of LMEs suitable for implementation on the coasts of developing countries was recommended by a panel of international experts that met at Cornell University in July 1991 (Sherman \& Laughlin 1992). The strategy included (1) regular trawling using a stratified random sampling design to measure changes in the fish community; (2) plankton surveys to measure biofeedback to perturbations at the planktonic trophic level; and (3) measurements on the effects of pollution. The large-scale changes in the fisheries of the North Sea and the Northeast Continental Shelf of the United States have been successfully detected using trawling techniques for several decades (Azarovitz \& Grosslein 1987). The surveys have been conducted by relatively large research vessels. However, standardized sampling procedures, when deployed from small calibrated trawlers, can provide important information on diverse changes in fish species. The fish catch provides biological samples for stomach analyses, age and growth, fecundity, and size comparisons (ICES 1991), data for clarifying and quantifying multispecies trophic relationships, and the collection of samples to monitor coastal pollution. Samples of trawl-caught fish can be used to monitor pathological conditions that may be associated with coastal pollution. The trawlers can also be used as platforms for obtaining water, sediment, and benthic samples for monitoring harmful algal blooms, virus vectors of disease, eutrophication, anoxia, and changes in benthic community studies. The plankton of LMEs can be measured by deploying Continuous Plankton Recorder (CPR) systems from commercial vessels of opportunity (Glover 1967). The advanced plankton recorders can be fitted with sensors for temperature, salinity, chlorophyll, nitrate/ nitrite, petroleum hydrocarbons, light, bioluminescence, and primary productivity (Aiken 1981, Aiken \& Bellan 1990, Williams \& Aiken 1990, UNESCO 1992, Williams 1993), providing the means to monitor changes in phytoplankton, zooplankton, primary productivity, species composition and dominance, and long-term changes in the physical and nutrient characteristics of the LME, as well as longer term changes relating to the biofeedback of the plankton to the stress of climate change (Colebrook 1986, Dickson et 
al. 1988, Jossi \& Smith 1990, Hayes et al. 1993, Jossi \& Goulet 1993, Williams 1993). Plankton monitoring using the CPR system is at present expanding in the North Atlantic (Colebrook et al. 1991). The implementation of the protocols for international mussel watch and methods for monitoring the frequency and extent of harmful algal blooms (Smayda 1991, IOC 1993a) and emergent vectors of disease (Epstein 1993) would provide the components of a balanced 'core' monitoring effort.

A critical feature of the LME monitoring strategy is the development of a consistent long-term data base for understanding interannual changes and multi-year trends in biomass yields for each of the LMEs. For example, during the late 1960 s and early 1970 s, when there was intense foreign fishing within the Northeast U.S. Continental Shelf Ecosystem, marked alterations in fish abundances were recorded. Significant shifts among species abundances were observed. The finfish biomass of important species (e.g. cod, haddock, flounders, herring, and mackerel) declined by approximately $50 \%$ (Fig. 6). This was followed by increases in the biomass of sand lance (Fig. 7) and elasmobranchs (dogfish and skates) (Fig. 8), and led to the conclusion that the overall carrying capacity of the ecosystem for finfish did not change. The excessive fishing effort on highly valued species allowed for low-valued species to increase in abundance. Analyses of catch-per-uniteffort and fishery-independent bottom trawling survey data were critical sources of information used to implicate overfishing as the cause of the shifts in relative abundance among the species of the fish community

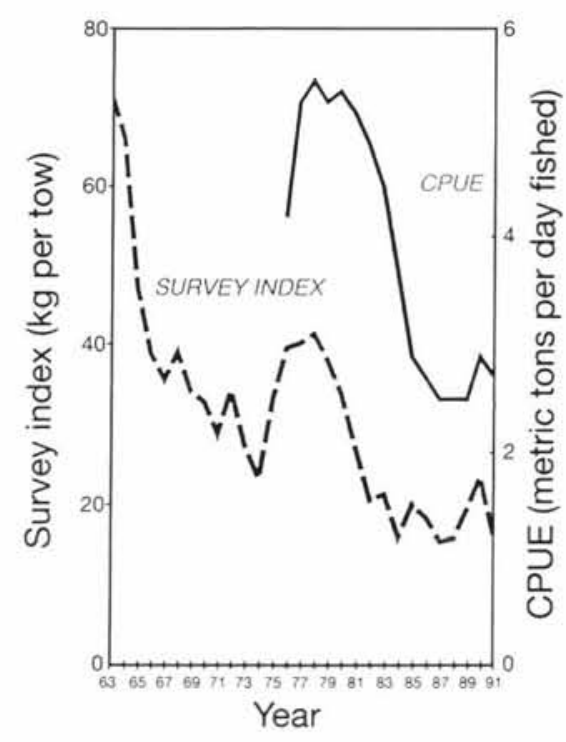

Fig. 6. Abundance indices for principal U.S. Northeast Continental Shelf groundfish resources from 1963 to 1991. (From Anthony 1993)

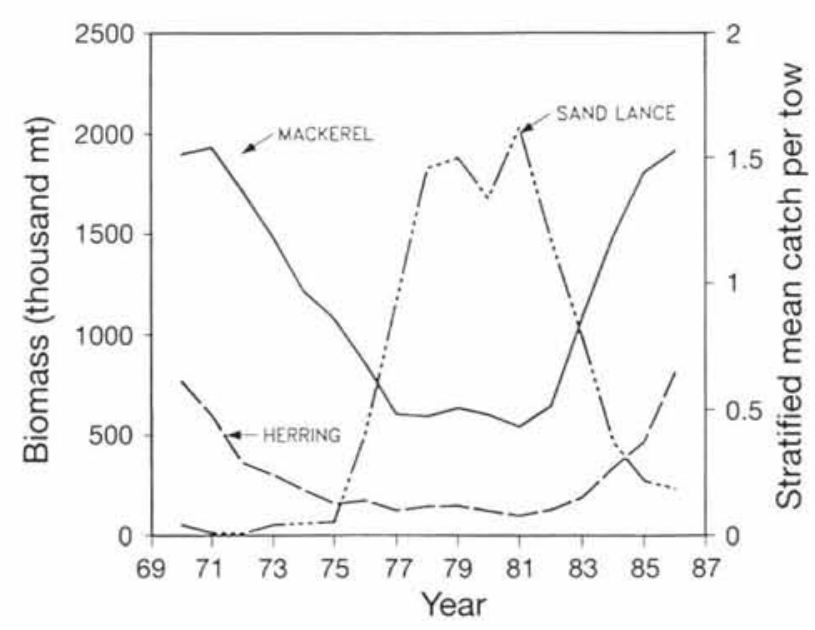

Fig. 7. Trends in biomass of mackerel (age $1+$ ) and herring (age $3+$ ) derived from virtual population analysis and trends in relative abundance [stratified mean catch per tow $(\mathrm{kg})$ ] of sand lance (age $2+$ ) based on research vessel surveys. (From Fogarty et al. 1991)

within the shelf ecosystem. It is important to note, however, that the lower-end of the food chain in the offshore waters of the ecosystem remained unchanged, largely as described by Bigelow (1926) and Riley et al. (1949), suggesting that ecosystem productivity remained high during a period of species dominance shifts among the fish community caused by human interventions through fishing (Sherman et al. 1983). The natural 'resilience' of the ecosystem in relation to recovery from stress can be documented in the recovery of mackerel to former (pre-1960) levels of abundance and the apparent recovery of herring to 1960 s

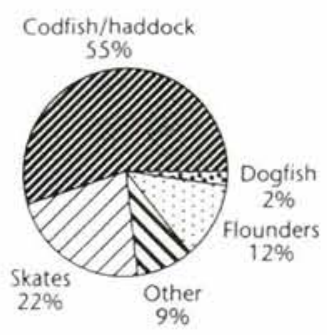

Georges Bank 1963

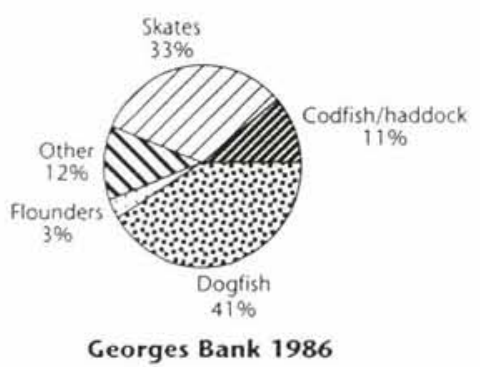

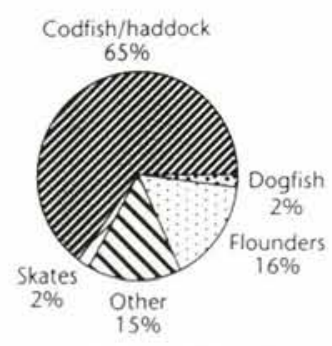

North Sea 1977-1985
Fig. 8. Species shift and abundance of small elasmobranchs (dogfish and skates) on Georges Bank within the Northeast Continental Shelf ecosystem of the United States compared with the North Sea Ecosystem. (Adapted from Anthony 1988) 
level of abundance on Georges Bank (Smith \& Morse 1990, Murawski 1991). The gyre systems of the Gulf of Maine and Georges Bank subsystems and the nutrient enrichment of the estuaries in the southern half of the Northeast Continental Shelf Ecosystem contribute to the maintenance on the shelf of relatively high levels of phytoplankton and zooplankton prey fields for planktivores including fish larvae, menhaden, herring, mackerel, sand lance, butterfish, and marine birds and mammals. However, excessive nutrient loadings of near-coastal waters appear to be contributing to a growing problem of eutrophication and increasing frequencies and extent of harmful algal blooms and associated biotoxic and anoxic events (Smayda 1991).

\section{CHANGING ECOSYSTEM STATES AND 'HEALTH' INDICES}

Ecosystem 'health' is a concept of wide interest for which a single precise scientific definition is problematical. Ecosystem health is used herein to describe the resilience, stability, productivity, biodiversity, and yield of the ecosystem in relation to the changing states of ecosystems. Methods to assess the health of LMEs are being developed from modifications to a series of indicators and indices described by several investigators (e.g. Costanza 1992, Rapport 1992, Norton \& Ulanowicz 1992, Karr 1992). The overriding objective is to monitor changes in health from an ecosystem perspective as a measure of the overall performance of a complex system (Costanza 1992). The health paradigm is based on the multiple-state comparisons of ecosystem resilience and stability (Pimm 1984, Holling 1986, Costanza 1992) and is an evolving concept. Definitions of several variables important to the changing states and health of marine ecosystems are given in Table 5. Following the definition of Costanza (1992), to be healthy and sustainable, an ecosystem must maintain its metabolic activity level, its internal structure and organization, and must be resistant to external stress over time and space frames relative to the ecosystem (Table 6). These concepts were discussed by panels of experts at 2 workshops convened in 1992 by NOAA (NOAA 1993). Among the indices discussed by the participants were 5 that are being considered as experimental measures of changing ecosystem states and health: (1) diversity, (2) stability, (3) yields, (4) productivity, and (5) resilience.

The data from which to derive the experimental indices are obtained from time-series monitoring of key ecosystem parameters. A prototype effort to validate the utility of the indices is under development by NOAA at the Northeast Fisheries Science Center. The ecosystem sampling strategy is focused on parameters relating to the resources at risk from overexploitation, species protected by legislative authority (marine mammals), and other key biological and physical components at the lower end of the food chain (plankton, nutrients, hydrography). The parameters of interest depicted in Fig. 9 include zooplankton composition, zooplankton biomass, water column structure, photosynthetically active radiation (PAR), transparency, chlorophyll $a, \mathrm{NO}_{2}, \mathrm{NO}_{3}$, primary production, pollution, marine mammal biomass, marine mammal composition, runoff, wind stress, seabird community structure, seabird counts, finfish composition, finfish biomass, domoic acid, saxitoxin, and paralytic shellfish poisoning (PSP). The experimental parameters selected incorporate the behavior of individuals, the resultant responses of populations and communities, as well as their interactions with the physical and chemical environment. The selected parameters, if measured in all LMEs, will permit comparison of relative changing states and health status among ecosystems. The interrelations between the data sets and the selected parameters are indicated by the arrows leading from column 1 to column 2 in the figure. The measured ecosystem components are shown in relation to ecosystem structure in a diagrammatic conceptualization of patterns and activities within the LME at different levels of complexity as depicted by Likens (1992) (Fig. 10).

Initial efforts to examine changing ecosystem states and relative health within a single ecosystem are underway for 4 subsystems of the U.S. Northeast Continental Shelf Ecosystem - Gulf of Maine, Georges Bank, Southern New England, Mid-Atlantic Bight. Initial studies of the structure, function, and productivity of the system have been reported (Sherman et al. 1988). It appears that the principal driving force in relation to sustainable ecosystem yield is fishing mortality expressed as predation on the fish stocks of the system, and that long-term sustainability of high economic yield species will be dependent on the application of significantly reduced fishing mortality measures and adaptive management strategies (Sissenwine 1986, Murawski 1991, Sissenwine \& Cohen 1991, Anthony 1993). Several alternative management strategies for reducing fishing effort on the fish stocks of the U.S. Northeast Continental Shelf Ecosystem are under consideration by the New England Fisheries Management Council and the Atlantic States Marine Fisheries Commission. In addition to fisheries management issues and significant biomass flips among dominant species, the Northeast Continental Shelf Ecosystem is also under stress from the increasing frequency of unusual plankton blooms, and eutrophication within the nearshore coastal zone resulting from high levels of phosphate and nitrate discharges into drainage 
Table 5. Definitions of some important variables for use in the indexing of changing ecosystem states ('health'). (Adapted and expanded from Costanza 1992)

\begin{tabular}{|c|c|c|}
\hline Variable & Definition & Units \\
\hline \multicolumn{3}{|l|}{ Stability } \\
\hline Homeostasis & $\begin{array}{l}\text { Maintenance of a steady state in living organisms by the use of feedback } \\
\text { control processes }\end{array}$ & \\
\hline Stable & $\begin{array}{l}\text { A system is stable if, and only if, the variables all return to the initial equilibrium } \\
\text { following their being perturbed from it. A system is locally stable if this return applies } \\
\text { to small perturbations, and globally stable if it applies to all possible perturbations }\end{array}$ & Binary \\
\hline Sustainable & $\begin{array}{l}\text { A system that can maintain its structure and function indefinitely. All non- } \\
\text { successional (i.e. climax) ecosystems are sustainable, but they may not be stable } \\
\text { (see resilience below). Sustainability is a policy goal for economic systems }\end{array}$ & Binary \\
\hline Resilience & $\begin{array}{l}\text { 1. How fast the variables return towards their equilibrium following a perturbation. } \\
\text { Not defined for unstable systems (Pimm 1984). } \\
2 \text {. The ability of a system to maintain its structure and patterns of behavior in the } \\
\text { face of disturbance (Holling 1986) }\end{array}$ & Time \\
\hline Resistance & The degree to which a variable is changed, following a perturbation & $\begin{array}{l}\text { Nondimensional } \\
\text { and continuous }\end{array}$ \\
\hline Variability & $\begin{array}{l}\text { The variance of population densities over time, or allied measures such as the } \\
\text { standard deviation or coefficient of variation ( } \mathrm{SD} / \mathrm{mean})\end{array}$ & \\
\hline \multicolumn{3}{|l|}{ Complexity } \\
\hline Species richness & The number of species in a system & Integer \\
\hline Connectance & $\begin{array}{l}\text { The number of actual interspecific interactions divided by the possible interspecific } \\
\text { interactions }\end{array}$ & Dimensionless \\
\hline Interaction strength & $\begin{array}{l}\text { The mean magnitude of interspecific interaction: the size of the effect of one species' } \\
\text { density on the growth rate of another species }\end{array}$ & \\
\hline Evenness & The variance of the species abundance distribution & \\
\hline Diversity indices & $\begin{array}{l}\text { Measures that combine evenness and richness with a particular weighting for each. } \\
\text { One important member of this family is the information theoretic index, } H\end{array}$ & Bits \\
\hline Ascendency & $\begin{array}{l}\text { An information theoretic measure that combines the average mutual information } \\
\text { (a measure of connectedness) and the total throughput of the system as a scaling } \\
\text { factor (see Ulanowicz 1992) }\end{array}$ & \\
\hline \multicolumn{3}{|l|}{ Other variables } \\
\hline Perturbation & A change to a system's inputs or environment beyond the normal range of variation & Varies \\
\hline Stress & A perturbation with a negative effect on a system & \\
\hline Subsidy & A perturbation with a positive effect on a system & \\
\hline
\end{tabular}

Table 6. Indices of vigor, organization, and resilience in various fields, including measures of gross primary product (GPP), net primary product (NPP), gross ecosystem product (GEP), and gross national product (GNP). (From Costanza 1992)

\begin{tabular}{|c|c|c|c|c|}
\hline $\begin{array}{l}\text { Component } \\
\text { of health }\end{array}$ & $\begin{array}{l}\text { Related } \\
\text { concepts }\end{array}$ & $\begin{array}{l}\text { Existing related } \\
\text { measures }\end{array}$ & $\begin{array}{l}\text { Fields } \\
\text { of origin }\end{array}$ & $\begin{array}{l}\text { Probable method } \\
\text { of solution }\end{array}$ \\
\hline \multirow[t]{3}{*}{ Vigor } & Function & GPP, NPP, GEP & Ecology & \multirow{3}{*}{ Measurement } \\
\hline & Productivity & GNP & Economics & \\
\hline & System throughput & Metabolism & Biology & \\
\hline \multirow[t]{2}{*}{ Organization } & Structure & Diversity index & & \multirow[b]{2}{*}{ Network analysis } \\
\hline & Biodiversity & $\begin{array}{l}\text { Average mutual information } \\
\text { Predictability }\end{array}$ & Ecology & \\
\hline \multicolumn{2}{|l|}{ Resilience } & Scope for growth & Ecology & \multirow{2}{*}{ Simulation modelling } \\
\hline Combinations & & Ascendancy & Ecology & \\
\hline
\end{tabular}




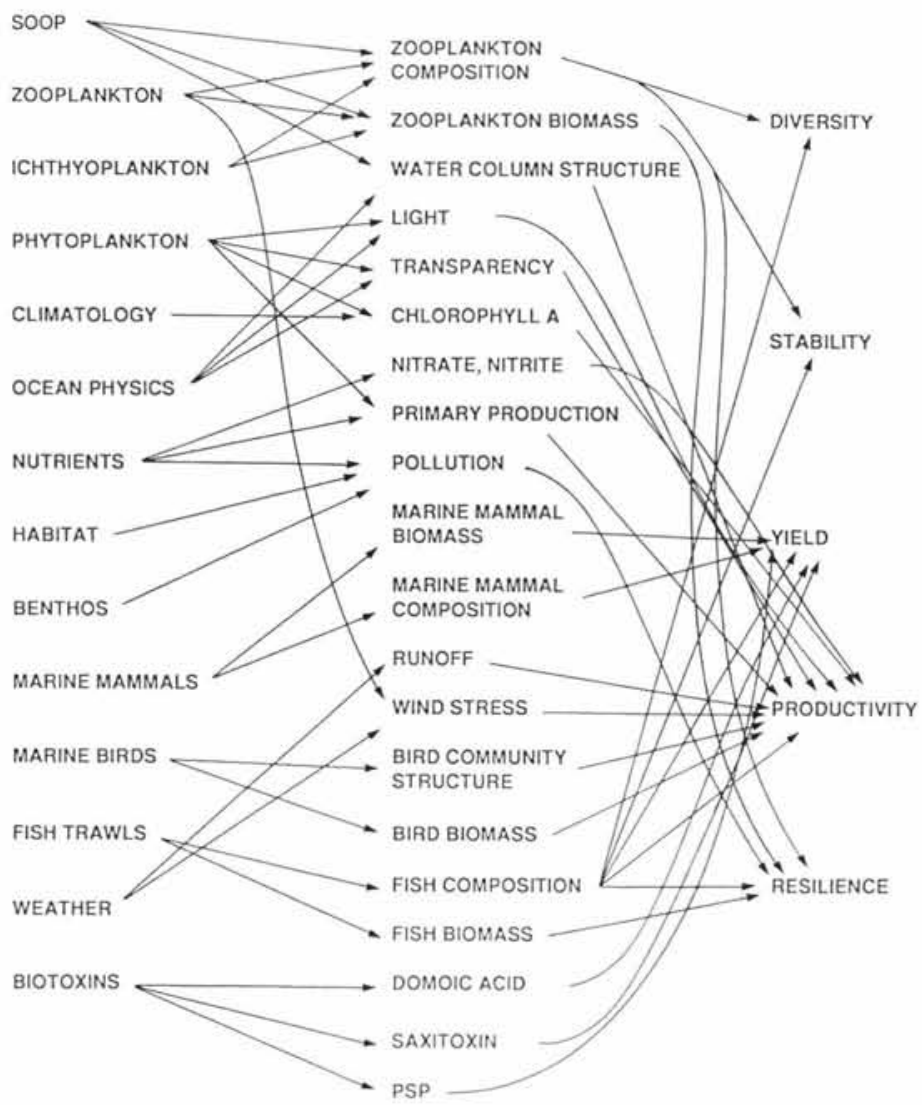

Fig. 9. A schematic representation of the data bases and experimental parameters for indexing the changing states of large marine ecosystems. The data base represents time-series measurements of key ecosystem components from the U.S. Northeast Continental Shelf ecosystem. Indices are based on changes compared with the ecosystem state in 1960

basins. Whether the increases in the frequency and extent of nearshore plankton blooms are responsible for the rise in incidence of biotoxin-related shellfish closures, marine mammal mortalities, and the recent discovery of disease-bearing viruses (Colwell \& Spira 1992, Epstein 1993) remains an important open question that is the subject of considerable concern to state and federal management agencies (Anderson 1989, Smayda 1991).

\section{PRESENT AND FUTURE ECOSYSTEM SUSTAINABILITY EFFORTS}

The topics of change and persistence in marine communities, and the need for multispecies and ecosystem perspectives in the sustainability of living marine resources were reviewed at the Dahlem Conference on
Exploitation of Marine Communities in 1984 (May 1984). Significant multispecies ecosystem-oriented studies in support of the management of marine resources have not been practiced until recently. In 1991, the Advisory Committee on Fisheries Management of ICES reached an important milestone by including guidance for providing 'the advice necessary to maintain viable fisheries within sustainable ecosystems'. The designation and management of LMEs is, at present, an evolving scientific and geopolitical process (Morgan 1988, Alexander 1989, AAAS 1993). Sufficient progress has been made to allow for useful comparisons among different processes influencing large-scale changes in the biomass yields of LMEs (Bax \& Laevastu 1990, Bakun 1993). Among the more recent findings is the marked decline in biodiversity among the principal fish stocks of the Black Sea, based, in part, on the introduction of a 'foreign' species of ctenophore that has undergone a population explosion causing severe predation on both early life-stages of fish and their prey (Mee 1992). The influence of changes in the gene-pool of wild stocks from inadvertent releases of cultured stocks is another concern of scientists engaged in LME studies.

Among the ecosystems being managed from a more holistic perspective are: the Yellow Sea Ecosystem, where the principal effort is underway by the Peoples Republic of China (Tang 1989); the multispecies fisheries of the Benguela Current Ecosystem under the management of the government of South Africa (Crawford et al. 1989); the Great Barrier Reef Ecosystem (Bradbury \& Mundy 1989, Kelleher 1993) and the Northwest Australian Continental Shelf Ecosystem (Sainsbury 1988) under management by the state and federal governments of Australia; the Antarctic marine ecosystem under the Commission for the Conservation of Antarctic Marine Living Resources (CCAMLR) and its 21-nation membership (Scully et al. 1986, Sherman \& Ryan 1988). Movement toward ecosystems management is emerging for the North Sea (NSTF 1991), the Barents Sea (Eikeland 1992), and the Black Sea (Hey \& Mee 1993). Within the EEZ of the United States, the state governments of Washington and Oregon have developed a comprehensive plan for the management of marine resources within the Northern California Current Ecosystem (Bottom et al. 1989).

The broad-spectrum approach to LME research and monitoring provides a conceptual framework for collaboration in process-oriented studies conducted by 


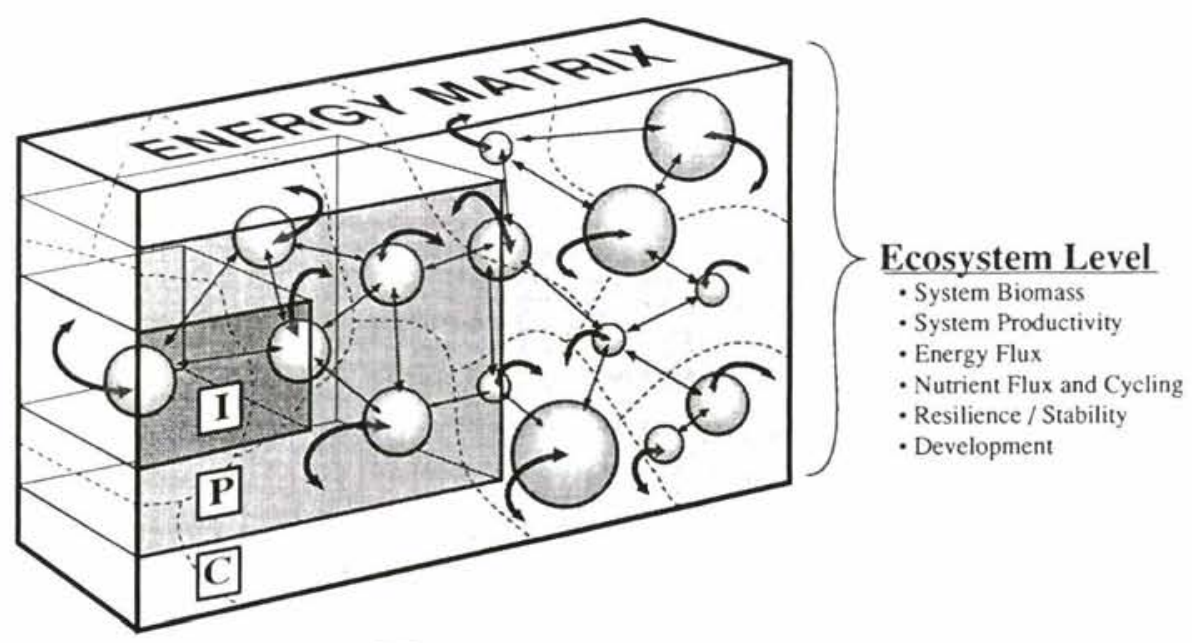

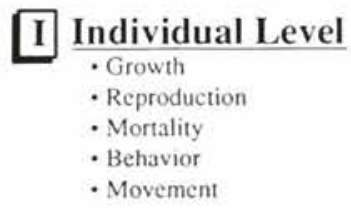

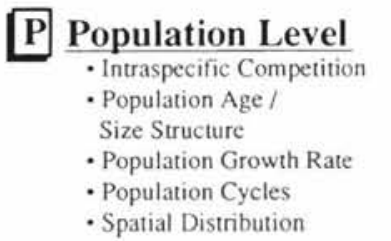

C Community Level

- Interspecific Competition

- Diversity

- Spatial Structure

- Zonation

- Succession

- Invasion / Extinction

- Indirect Competition /

Mutualism

Fig. 10. Diagrammatic conceptualization of patterns and activities at different levels of complexity. Each sphere represents an individual abiotic or biotic entity. Abiotic is defined as nonliving matter. Broad, double-headed arrows indicate feedback between entities and the energy matrix for the system. The thin arrows represent direct interactions between individual entities. Much of ecology is devoted to studying interactions between biotic and abiotic entities with a focus on the effects of such interactions on individuals (I), populations (P), or communities (C) of organisms. Ecosystem ecology studies these interactions from the viewpoint of their effect on both the biotic and abiotic entities and within the context of the system. The boundaries of the system must be established to conduct quantitative studies of flux. Fig. 1 depicts the boundaries of LMEs, located around the margins of the ocean basins, where the influence of overexploitation, pollution, and habitat degradation and climate change are affecting the structure and function of the ecosystems. (From Likens 1992)

the National Science Foundation (NSF)-NOAA sponsored GLOBal ocean ECosystems dynamics (GLOBEC 1991) program in the United States and the International GLOBEC Program. Developing LME monitoring strategies are compatible with the proposed Global Ocean Observing System (GOOS) of the IOC (1992b) and those modules to be focused on living marine resources and ecosystem health (IOC 1993b).

Efforts are underway to place greater focus on the linkage between scientific and societal needs and the utility of long-term, broad-area coastal ocean assessment and monitoring studies aimed at enhancing the long-term sustainability of marine resources. If the proposition for time-series monitoring of changing ecosystem states is to be realized in this period of shrinking budgets, it would be in the best interests of science and socio-economic interests to be tightly linked in the endeavor. The basis for the linkage was emphasized not only in the UNCED declarations on the oceans, but also in a series of recent developments revolving around: (1) global climate change; (2) legal precedent for international cooperation implicit in the
Law of the Sea; (3) a growing interest in marine ecosystems as regional units for marine research, monitoring, and management; (4) the effort of the IOC to encourage the implementation of a GOOS; and (5) renewed national interests in improving the health of degraded coastal ecosystems. In the United States, this interest has resulted in the enactment of recent legislation mandating the establishment of a national coastal monitoring program for assessing the changing states of 'coastal ecosystem health' and reporting the findings to the U.S. Congress as a recurring biannual responsibility of NOAA and EPA (NCMA 1992).

A more holistic approach to coastal ecosystems assessment and monitoring as a means for fostering international cooperation in achieving sustainability objectives for marine resources between the more developed and less developed countries is presently underway. The 49 large marine ecosystems that have been identified for comparative sustainability studies are located around the margins of the ocean basins and extend over the coastlines of several countries. They are in regions of the world ocean most affected 
by overexploitation, pollution, and habitat degradation, and collectively represent target areas for mitigation effort, particularly in the stressed coastal ecosystems adjacent to centers of population densities in developing countries. The Global Environment Facility (GEF) of the World Bank, in collaboration with NOAA, IOC, UNEP, FAO, Natural Environment Research Council (NERC), the Sir Alister Hardy Foundation for Ocean Science, and scientists from national marine resource agencies of several of the more developed countries (e.g. Belgium, Canada, Denmark, France, Germany, The Netherlands, Norway, and the United Kingdom) are prepared to assist developing nations in implementing coastal ecosystem assessment, monitoring, and mitigation programs aimed at providing a scientific basis for improving the prospects for the long-term sustainable development of marine resources (Sherman et al. 1992a). Two of these programs are in the advanced planning stage, one for the Gulf of Guinea Ecosystem that brings together, into a single program effort, 5 countries of the region-Ivory Coast, Ghana, Nigeria, Benin, and Cameroon. The other program is being developed jointly by marine specialists from China and Korea for the Yellow Sea Ecosystem (Wu \& Qiu 1993). The first of these projects is scheduled to be implemented in the Gulf of Guinea LME in summer, 1994.

A comprehensive regional project to assess, monitor, and mitigate stresses on the Black Sea Ecosystem is being supported by the GEF (Mee 1992). It appears that marine resource managers and scientists are being responsive to management needs by reversing the cancellation of monitoring programs described recently by Duarte et al. (1992), and that monitoring initiatives related to the support of a more comprehensive systems approach to ensuring the long-term sustainability of marine resources are likely to be underway once again in marine ecosystems of Europe, North America, Africa, and Asia.

The growing partnership among funding agencies, marine ecologists, and socioeconomic interests mark an important step toward realization of the UNCED declaration aimed at reversing the declining condition of coastal ecosystems, and enhancing the long-term sustainability of marine resources.

\section{LITERATURE CITED}

AAAS (American Association for the Advancement of Sciences) (1986). Variability and management of large marine ecosystems. AAAS Selected Symp. 99. Westview Press, Inc., Boulder

AAAS (1989). Biomass yields and geography of large marine ecosystems. AAAS Selected Symp. 111. Westview Press, Inc., Boulder

AAAS (1990). Large marine ecosystems: patterns, processes and yields. AAAS Press, Washington, DC

AAAS (1991). Food chains, yields, models, and management of large marine ecosystems. Westview Press, Inc., Boulder

AAAS (1993). Large marine ecosystems: stress, mitigation, and sustainability. AAAS Press, Washington, DC

Aiken, J. (1981). The Undulating Oceanographic Recorder Mark 2. J. Plankton Res. 3: 551-560

Aiken, J., Bellan, I. (1990). Optical oceanography: an assessment of a towed method. In: Herring, P. J., Campbell, A. K., Whitfield, M., Maddock, L. (eds.) Light and life in the sea. Cambridge Univ. Press, London, p. 39-57

Alexander, L. M. (1989). Large marine ecosystems as global management units. In: Sherman, K., Alexander, L. M. (eds.) Biomass yields and geography of large marine ecosystems. American Association for the Advancement of Science (AAAS) Selected Symp, 111. Westview Press, Inc., Boulder, p. 339-344

Alheit, J., Bernal, P. (1993). Effects of physical and biological changes on the biomass yield of the Humboldt Current ecosystem. In: Sherman, K., Alexander, L. M., Gold, B. D. (eds.) Large marine ecosystems: stress, mitigation, and sustainability. AAAS Press, Washington, DC

Alverson, D. L., Longhurst, A. R., Gulland, J. A. (1970). How much food from the sea? Science 168: 503-505

Andersen, K. P., Ursin, E. (1977). A multispecies extension to the Beverton and Holt Theory of Fishing with accounts of phosphorus circulation and primary production. Medd. Dan. Fish.-Havunders. N.S. 7:319-435

Anderson, D. M. (1989). Toxic algal blooms and red tides: a global perspective. In: Okaichi, T., Anderson, D. M., Nemoto, T. (eds.) Red tides: biology, environmental science, and toxicology. Elsevier, New York, p. 11-16

Anthony, V. C. (1988). The New England fisheries in the 21st century. Nat. Mar. Fish. Serv., Northeast Fish. Sci. Ctr., Woods Hole, MA

Anthony, V. C. (1993). The state of groundfish resources off the northeastern United States. Fisheries 18(3): 12-17

Azarovitz, T. R., Grosslein, M. D. (1987). Fishes and squids. In: Backus, R. H. (ed.) Georges Bank. MIT Press, Cambridge, MA, p. $315-346$

Bakun, A. (1993). The California Current, Benguela Current, and Southwestern Atlantic Shelf ecosystems: a comparative approach to identifying factors regulating biomass yields. In: Sherman, K., Alexander, L. M., Gold, B. D. (eds.) Large marine ecosystems: stress, mitigation, and sustainability. AAAS Press, Washington, DC, p. 199-221

Bax, N. J., Laevastu, T. (1990). Biomass potential of large marine ecosystems: a systems approach. In: Sherman, K., Alexander, L. M., Gold, B. D. (eds.) Large marine ecosystems: patterns, processes and yields. AAAS Press, Washington, DC, p. 188-205

Beddington, J. R. (1984). The response of multispecies systems to perturbations. In: May, R. M. (ed.) Exploitation of marine communities. Springer-Verlag, Berlin, p. 209-255

Beddington, J. R. (1986). Shifts in resource populations in large marine ecosystems. In: Sherman, K., Alexander, L. M. (eds.) Variability and management of large marine ecosystems. AAAS Selected Symp. 99. Westview Press, Inc., Boulder, p. 9-18

Belsky, M. H. (1986). Legal constraints and options for total ecosystem management of large marine ecosystems. In: Sherman, K., Alexander, L. M. (eds.) Variability and management of large marine ecosystems. AAAS Selected Symposium 99. Westview Press, Inc., Boulder, p. 241-261

Belsky, M. H. (1989). The ecosystem model mandate for a comprehensive United States ocean policy and Law of the Sea. San Diego L. Rev. 26(3): 417-495 
Beverton, R. J. H., Holt, S. J. (1957). On the dynamics of exploited fish populations. Fish. Invest. Minist. Agric. Fish. Food (G.B.) Ser. II 19: 1-533

Bigelow, H. B. (1926). Plankton of the offshore waters of the Gulf of Maine. Bulletin of the Bureau of Fisheries, XL, Part 2. Government Printing Office, Washington, DC

Blindheim, J., Skjoldal, H. R. (1993). Effects of climatic changes on the biomass yield of the Barents Sea, Norwegian Sea, and West Greenland Sea large marine ecosystems. In: Sherman, K., Alexander, L. M., Gold, B. D. (eds.) Large marine ecosystems: stress, mitigation, and sustainability. AAAS Press, Washington, DC, p. 185-198

Bombace, G. (1993). Ecological and fishing features of the Adriatic Sea. In: Sherman, K., Alexander, L. M., Gold, B. D. (eds.) Large marine ecosystems: stress, mitigation, and sustainability. AAAS Press, Washington, DC, p. 119-136

Borisov, V. (1991). The state of the main commercial species of fish in the changeable Barents Sea ecosystem. In: Sherman, K., Alexander, L. M., Gold, B. D. (eds.) Food chains, yields, models, and management of large marine ecosystems. Westview Press, Inc., Boulder, p. 193-203

Bottom, D. L., Jones, K. K., Rodgers, J. D., Brown, R. F. (1989). Management of living resources: a research plan for the Washington and Oregon continental margin. National Coastal Resources Research and Development Institute, Newport, OR. NCRI-T-89-004

Bradbury, R. H., Mundy, C. N. (1989). Large-scale shifts in biomass of the Great Barrier Reef ecosystem. In: Sherman, K., Alexander, L. M. (eds.) Biomass yields and geography of large marine ecosystems. AAAS Selected Symp. 111. Westview Press, Inc., Boulder, p. 143-167

Byrne, J. (1986). Large marine ecosystems and the future of ocean studies. In: Sherman, K., Alexander, L. M. (eds.) Variability and management of large marine ecosystems. AAAS Selected Symp. 99. Westview Press, Inc., Boulder, p. 299-308

Caddy, J. (1993), Contrast between recent fishery trends and evidence for nutrient enrichment in two large marine ecosystems: the Mediterranean and the Black Seas. In: Sherman, K., Alexander, L. M., Gold, B. D. (eds.) Large marine ecosystems: stress, mitigation, and sustainability. AAAS Press, Washington, DC, p. 137-147

Canon, J. R. (1986). Variabilidad ambiental en relacion con la pesqueria neritica pelagica de la zona Norte de Chile. In: Arana, P. (ed.) La pesca en Chile. Escuela de Ciencias del Mar, Facultad de Recursos Naturales, Universidad Catolica de Valparaiso, Chile, p. 195-205

Christy, F. T. Jr (1986). Can large marine ecosystems be managed for optimum yields? In: Sherman, K., Alexander, L. M. (eds.) Variability and management of large marine ecosystems. AAAS Selected Symp. 99. Westview Press, Inc., Boulder, p. 263-267

Colebrook, J. M. (1986). Environmental influences on longterm variability in marine plankton. Hydrobiologia 142: $309-325$

Colebrook, J. M., Warner, A. J., Proctor, C. A., Hunt, H. G., Pritchard, P., John, A. W. G. Joyce, D., Barnard, R. (1991). 60 years of the continuous plankton recorder survey: a celebration. The Sir Alister Hardy Foundation for Ocean Science, Plymouth, England

Collie, J. S. (1991). Adaptive strategies for management of fisheries resources in large marine ecosystems. In: Sherman, K., Alexander, L. M., Gold, B. D. (eds.) Food chains, yields, models, and management of large marine ecosystems. Westview Press, Inc., Boulder, p. 225-242

Colwell, R. R., Spira, W. M. (1992). The ecology of Vibrio cholerae. In: Barua, D., Greenough, W. B. III (eds.) Cholera. Plenum Medical Book Company, New York, p. 107-127
Costanza, R. (1992). Toward an operational definition of ecosystem health. In: Costanza, R., Norton, B. G., Haskell, B. D. (eds.) Ecosystem health: new goals for environmental management. Island Press, Washington, DC, p. 239-256

Crawford, R. J. M., Shannon, L. V., Shelton, P. A. (1989). Characteristics and management of the Benguela as a large marine ecosystem. In: Sherman, K., Alexander, L. M. (eds.) Biomass yields and geography of large marine ecosystems. AAAS Selected Symp. 111. Westview Press, Inc., Boulder, p. 169-219

Cushing, D. H. (1975). Marine ecology and fisheries. Cambridge Univ. Press, London

Daan, N. (1986). Results of recent time-series observations for monitoring trends in large marine ecosystems with a focus on the North Sea. In: Sherman, K., Alexander, L. M. (eds.) Variability and management of large marine ecosystems. AAAS Selected Symp. 99. Westview Press, Inc., Boulder, p. $145-174$

Dickson, R. R., Kelly, P. M., Colebrook, J. M., Wooster, W. S. Cushing, D. H. (1988). North winds and production in the eastern North Atlantic. J. Plankton Res. 10: 151-169

Duarte, C. M., Cebrian, J., Marba, N. (1992). Uncertainty of detecting sea change. Nature 356: 190

Eikeland, P. O. (1992). Multispecies management of the Barents Sea large marine ecosystem: a framework for discussing future challenges. The Fridtjof Nansen Institute, Polhogda, Postboks 326, Fridtjof Nansens vei 17, N-1324 Lysaker, Norway. R: 004-1992; ISBN: 82-7613-030-5; ISSN: 0801-2431

Ellertsen, B., Fossum, P., Solemdal, P., Sundby, S., Tilseth, S. (1990). Environmental influence on recruitment and biomass yields in the Norwegian Sea Ecosystem. In: Sherman, K., Alexander, L. M., Gold, B. D. (eds.) Large marine ecosystems: patterns, processes, and yields. AAAS Press, Washington, DC, p. 19-35

Epstein, P. R. (1993). Algal blooms and public health. World Resour. Rev. 5(2): 190-206

Farrington, J. W., Goldberg, E. D., Risebrough, R. W., Martin, J. H., Bowen, V. T. (1983). U.S. 'Musselwatch' 1976-1978: an overview of the trace metal, DDE, PCB, hydrocarbon and artificial radionuclide data. Environ. Sci. Technol. 17: 490-496

FAO (Food and Agriculture Organization of the UN). (1992). FAO yearbook of fishery statistics, Vol. 70 (for 1990). FAO, Rome

Fogarty, M., Cohen, E. B., Michaels, W. L., Morse, W. W. (1991). Predation and the regulation of sand lance populations: an exploratory analysis. ICES Mar. Sci. Symp. 193: $120-124$

GESAMP (Group of Experts on the Scientific Aspects of Marine Pollution) (1990). The state of the marine environment. UNEP Regional Seas Reports and Studies No. 115, Nairobi

GLOBEC (GLOBal Ocean ECosystems Dynamics) (1991). Report No. 1. Initial science plan, February 1991. Produced by Joint Oceanographic Institutions Inc., Washington, DC

Glover, R. S. (1967). The continuous plankton recorder survey of the North Atlantic. Symp. Zool. Soc. Lon. 19: 189-210

Goldberg, E. D. (1976) The health of the oceans. UNEC Press, Paris

Gulland, J. A. (1984). Epilogue. In: Exploitation of marine communities. May, R. M. (ed.) Springer-Verlag, Berlin, p. $335-337$

Hayes, G. C., Carr, M. R., Taylor, A. H. (1993). The relationship between gulf stream position and copepod abundance derived from the Continuous Plankton Recorder 
survey: separating the biological signal from sampling noise. J. Plankton Res. 15: 1359-1373

Hempel, G. (ed.) (1978). Symposium on North Sea fish stocks - Recent changes and their causes. Rapp. P.-v. Réun. Cons, int. Explor. Mer 172: 1-449

Hey, E. (1992). A healthy North Sea ecosystem and a healthy North Sea fishery: two sides of the same regulation? Ocean Develop. int. Law 23: 217-238

Hey, E., Mee, L. D. (1993). Black Sea. The ministerial declaration: an important step. Environ. Pol. Law 2315: 215-217. $235-236$

Holling, C. S. (1973). Resilience and stability of ecological systems. Institute of Resource Ecology, Univ, British Columbia, Vancouver

Holling, C. S. (1986). The resilience of terrestrial ecosystems local surprise and global change. In: Clark, W. C., Munn, R. E. (eds.) Sustainable development of the biosphere. Cambridge Univ. Press, London, p. 292-317

Holling, C. S. (1993). Investing in research for sustainability. Ecol. Appl. 3: 552-555

Hovgaard, H., Buch, E. (1990). Fluctuation in the cod biomass of the West Greenland Sea ecosystem in relation to climate. In: Sherman, K., Alexander, L. M., Gold, B. D. (eds.) Large marine ecosystems: patterns, processes and yields. AAAS Press, Washington, DC, p. 36-43

ICES (International Council for the Exploration of the Sea) (1988). Results of the 1985 baseline study of contaminants in fish and shellfish. Cooperative Research Report No. 151. ICES, Copenhagen

ICES (1991). Report of the Multispecies Assessment Working Group. Comm. Meet. int. Coun. Explor. Sea ICES-C.M. 1991/Assess: 7

IGBP (International Geosphere-Biosphere Programme), (1994). IGBP in action: Work plan 1994-1998. Global Change Report No. 28. The International Geosphere-Biosphere Programme: a study of global change of the International Council of Scientific Unions (ICSU), Stockholm

IOC (International Oceanographic Commission of UNESCO). (1992a). Global Ocean Observing System (GOOS), An initiative of the Intergovernmental Oceanographic Commission (of UNESCO). IOC, UNESCO, Paris

IOC (1992b). The use of large marine ecosystem concept in the Global Ocean Observing System (GOOS). Twentyfifth Session of the IOC Executive Council, Paris, 10-18 March 1992. IOC/EC-XXV/Inf. 7

IOC (1993a). Intergovernmental Oceanographic Commission - Outline of a HAB training and capacity building program. Second Session of the Joint IOC-FAO Intergovernmental Panel on Harmful Algal Blooms, Paris, 14-16 October 1993. IOC-FAO/IPHAB-II/Inf. 6

IOC (1993b). Report of the IOC Blue Ribbon Panel for a Global Ocean Observing System (GOOS). The case for GOOS. IOC/INF-915 Corr. Paris, 23 February 1993. SC-93/WS3

IUCN (International Union for Conservation of Nature and Natural Resources) (1990). Caring for the world. A strategy for sustainability. Second Draft, June 1990, prepared by the World Conservation Union (IUCN), the United Nations Environment Programme (UNEP), and the World Wide Fund for Nature (WWF), Gland, Switzerland

Jossi, J. W., Goulet, J. R. Jr (1993), Zooplankton trends: U.S. north-east shelf ecosystem and adjacent regions differ from north-east Atlantic and North Sea. ICES J. Mar. Sci. 50: $303-313$

Jossi, J. W., Smith, D. E. (1990). Continuous plankton records: Massachusetts to Cape Sable, N.S., and New York to the Gulf Stream, 1989. NAFO Ser. Doc. 90/66: 1-11
Karr, J. (1992). Ecological integrity: protecting earth's life support systems. In: Costanza, R., Norton, B. G. Haskell, B. D. (eds.) Ecosystem health: new goals for environmental management. Island Press, Washington, DC, p. 223-238

Kawasaki, T., Tanaka, S., Toba, Y., Taniguchi, A. (eds.) (1991). Long-term variability of pelagic fish populations and their environment. Proc. int. Symp., Sendai, Japan, 14-18 November 1989. Pergamon Press, Tokyo

Kelleher, G. (1993). Sustainable development of the Great Barrier Reef as a large marine ecosystem. In: Sherman, K., Alexander, L. M., Gold, B. D. (eds.) Large marine ecosystems: stress, mitigation, and sustainability. AAAS Press, Washington, DC, p. 272-279

Kullenberg, G. (1986). Long-term changes in the Baltic Ecosystem. In: Sherman, K., Alexander, L. M. (eds.) Variability and management of large marine ecosystems. AAAS Selected Symp. 99. Westview Press, Inc., Boulder, p. 19-32

Lasker, R. (1988). Food chains and fisheries: an assessment after 20 years. In: Rothschild, B. J. (ed.) Toward a theory on biological-physical interactions in the world ocean. NATO ASI Series. Series C: Mathematical and physical sciences, Vol. 239. Kluwer Academic Publishers, Dordrecht, p. 173-182

Levin, S. A. (1990). Physical and biological scales, and modelling of predator-prey interactions in large marine ecosystems. In: Sherman, K., Alexander, L. M., Gold, B. D. (eds.) Large marine ecosystems: patterns, processes, and yields. AAAS Press, Washington, DC, p. 179-187

Levin, S. A. (1993). Approaches to forecasting biomass yields in large marine ecosystems. In: Sherman, K., Alexander, L. M., Gold, B. D. (eds.) Large marine ecosystems: stress, mitigation, and sustainability. AAAS Press, Washington, DC, p. 36-39

Likens, G. E. (1992). The ecosystem approach: its use and abuse. In: Kinne, O. (ed.) Excellence in ecology, Vol. 3. Ecology Institute, Oldendorf/Luhe

Lindemann, R. L. (1942). The trophic dynamic aspect of ecology. Ecology 23: 399-418

Lubchenco, J., Olson, A. M., Brubaker, L. B., Carpenter, S. R. Holland, M. M., Hubbell, S. P., Levin, S. A., MacMahon, J. A., Matson, P. A., Melillo, J. M., Mooney, H. A., Peterson, C. H., Pulliam, H. R., Real, L. A., Regal, P. J., Risser, P. G. (1991). The sustainable biosphere initiative: an ecological research agenda. Ecology 72: 371-412

Ludwig, D., Hilborn, R., Walters, C. (1993). Uncertainty, resource exploitation, and conservation: lessons from history. Science 260: 17,36

MacCall, A. D. (1986). Changes in the biomass of the California Current system. In: Sherman, K., Alexander, L. M. (eds.) Variability and management of large marine ecosystems. AAAS Selected Symp. 99. Westview Press, Inc., Boulder, p. 33-54

Malone, T, C. (1991). River flow, phytoplankton production and oxygen depletion in Chesapeake Bay. In: Tyson, R. V., Pearson, T. H. (eds.) Modern and ancient continental shelf anoxia. Geological Society Spec. Publ. No. 58: 83-93

Mangel, M. (1991). Empirical and theoretical aspects of fisheries yield models for large marine ecosystems. In: Sherman, K., Alexander, L. M., Gold, B. D. (eds.) Food chains, yields, models, and management of large marine ecosystems. Westview Press, Boulder, p. 243-261

Mangel, M., Hofman, R. J., Norse, E. A., Twiss, J. R. Jr (1993). Sustainability and ecological research. Ecol. Appl. 3(4): 573-575

May, R. M. (ed.). (1984). Exploitation of marine communities. Springer-Verlag, Berlin 
Mee, L. (1992). The Black Sea in crisis: a need for concerted international action. Ambio 21(4): 1278-1286

Minoda, T. (1989). Oceanographic and biomass changes in the Oyashio Current ecosystem. In: Sherman, K., Alexander, L. M. (eds.) Biomass yields and geography of large marine ecosystems. AAAS Selected Symp. 111. Westview Press, Inc., Boulder, p. 67-93

Morgan, J. R. (1988). Large marine ecosystems: an emerging concept of regional management. Environment 29(10): $4-9,26-34$

Morgan, J. R. (1989). Large marine ecosystems in the Pacific Ocean. In: Sherman, K., Alexander, L. M. (eds.) Biomass yields and geography of large marine ecosystems. AAAS Selected Symp. 111. Westview Press, Inc., Boulder, p. 377-394

Myers, N. (1990). Working towards one world. Book review. Nature 344(6266): 499-500

Murawski, S. A. (1991). Can we manage our multispecies fisheries? Fisheries 16(5): 5-13

NCMA (National Coastal Monitoring Act). (1992). One Hundred Second Congress of the United States of America, at the Second Session. 1992, The National Oceanic and Atmospheric Administration Authorization Act of 1992, H.R.2130, Washington, DC, October 29, 1992

NOAA (National Oceanic and Atmospheric Administration). (1993). Emerging theoretical basis for monitoring changing states (health) of large marine ecosystems. Summary reports of two workshops: Narragansett, RI, April 1992; Cornell University - July 1992. In: Sherman, K. (ed.) NOAA Technical Memorandum NMFS-F/NEC-100

NRC (National Research Council). (1990). Managing troubled waters: the role of marine environmental monitoring. National Academy Press, Washington, DC

NSTF (North Sea Task Force). (1991). Scientific activities in the framework of the North Sea Task Force. North Sea Environment Report No. 4. North Sea Task Force, Oslo and Paris Commissions, International Council for the Exploration of the Sea, London

Norton, B. G., Ulanowicz, R. E. (1992). Scale and biodiversity policy: a hierarchical approach. Ambio 21(3): 244-249

O'Connor, T. P., Ehler, C. N. (1991). Results from the NOAA National Status and Trends Program on distribution and effects of chemical contamination in the coastal and estuarine United States. Environ. Monitor. Assess. 17: 33-49

Overholtz, W. J., Nicolas, J. R. (1979). Apparent feeding by the fin whale Balaenoptera physalus, and humpback whale, Megoptera novaeangliae, on the American sand lance, Ammodytes americanus, in the Northwest Atlantic. Fish. Bull. U.S. 77: 285-287

Payne, P. M., Wiley, D. N., Young, S. B., Pittman, S., Clapham, P. J., Jossi, J. W. (1990). Recent fluctuations in the abundance of baleen whales in the southern Gulf of Maine in relation to changes in selected prey. Fish. Bull. U.S. 88: $687-696$

Pimm, S. L. (1984). The complexity and stability of ecosystems. Nature 307: 321-326

Postma, H., Zijlstra, J. J. (eds.). (1988). Ecosystems of the world 27: continental shelves. Elsevier, Amsterdam

Powers, K. D., Brown, R. G. B. (1987). Seabirds, Chap. 34. In: Backus, R. H. (ed.) Georges Bank. MIT Press, Cambridge, MA, p. 359-371

Prescott, J. R. V. (1989). The political division of large marine ecosystems in the Atlantic Ocean and some associated seas. In: Sherman, K., Alexander, L. M. (eds.) Biomass yields and geography of large marine ecosystems. AAAS Selected Symp. 111. Westview Press, Inc., Boulder, p. 395-442

Rapport, D. J. (1992). What is clinical ecology? In: Costanza,
R., Norton, B. G., Haskell, B. D. (eds.) Ecosystem health new goals for environmental management. Island Press Washington, DC, p. 144-156

Ricklefs, R. E. (1987). Community diversity: relative roles of local and regional processes. Science 235(4785): 167-171

Riley, G. A., Stommel, H., Bumpus, D. F. (1949). Quantitative ecology of the plankton of the western North Atlantic. Bull. Bingham Oceanogr. Coll. XII (3): 1-169

Rosenberg, A. A., Fogarty, M. J., Sissenwine, M. P., Beddington, J. R., Shepherd, J. G. (1993). Achieving sustainable use of renewable resources. Science 262: 828-829

Ryther, J. H. (1969). Relationship of photosynthesis to fish production in the sea. Science 166: 72-76

Sainsbury, K. J. (1988). The ecological basis of multispecies fisheries, and management of a dermersal fishery in tropical Australia. In: Gulland, J. A. (ed.) Fish population dynamics, 2nd edn. John Wiley \& Sons, New York, p. $349-382$

Schaefer, M. B. (1954). Some aspects of the dynamics of populations important to the management of the commercial marine fisheries. Bull. Inter-Am. Trop. Tuna Comm. 1 $27-56$

Scully, R. T., Brown, W. Y., Manheim, B. S. (1986). The Convention for the Conservation of Antarctic Marine Living Resources: a model for large marine ecosystem management. In: Sherman, K., Alexander, L. M. (eds.) Variability and management of large marine ecosystems. AAAS Selected Symp. 99. Westview Press, Inc., Boulder. p. 281-286

Scully, R. T. (1993). Convention on the Conservation of Antarctic Marine Living Resources. In: Sherman, K., Alexander, L. M., Gold, B. D. (eds.) Large marine ecosystems: Stress, mitigation, and sustainability. AAAS Press, Inc., Washington, DC, p. 242-251

She, J. (1993). Monitoring and researches on pollution/ environment and their ecological effects in YSLME. J. Oceanogr. Huanghai Bohai Seas 11(3): 69

Shelton, P. A., Boyd, A. J., Armstrong, M. J. (1985). The influence of large-scale environmental processes on neritic fish populations in the Benguela Current system. Calif. Coop. Oceanic Fish. Invest. Rep. 26: 72-92

Sherman, K. (1991). The large marine ecosystem concept: A research and management strategy for living marine resources. Ecol. Applications 1(4): 349-360

Sherman, K. (1993). Emerging theoretical basis for monitoring changing states (health) of large marine ecosystems. U.S. Dept of Commerce, NOAA Tech. Mem. NMFS-F/NEC100

Sherman, K., Green, J. R., Goulet, J. R., Ejsymont, L. (1983). Coherence in zooplankton of a large Northwest Atlantic Ecosystem. Fish. Bull. U.S. 81: 855-62

Sherman, K., Grosslein, M., Mountain, D., Busch, D., O'Reilly, J., Theroux, R. (1988). The continental shelf ecosystem off the northeast coast of the United States. In: Postma, H. Zilstra, J. J. (eds.) Ecosystems of the world 27: continental shelves, Chap. 9. Elsevier, Amsterdam, p. 279-337

Sherman, K., Jaworski, N., Smayda, T. (1992a). The Northeast Shelf Ecosystem: stress, mitigation, and sustainability, 12-15 August 1991 Symposium Summary. U.S. Dept of Commerce, NOAA Tech. Mem. NMFS-F/NEC-94

Sherman, K., Laughlin, T. (eds) (1992). Large marine ecosystems monitoring workshop report. U.S. Dept of Commerce, NOAA Tech. Mem. NMFS-F/NEC-93

Sherman, K., Ryan, A. F. (1988). Antarctic marine living resources. Oceanus 31(2): 59-63

Sherman, K., Skjoldal, H., Williams, R. (1992b). Global ocean monitoring. Nature 359: 769 
Sissenwine, M. P. (1986). Perturbation of a predator-controlled continental shelf ecosystem. In: Sherman, K., Alexander, L. M. (eds.) Variability and management of large marine ecosystems. AAAS Selected Symp. 99. Westview Press, Inc., Boulder, p. 55-85

Sissenwine, M. P., Cohen, E. B. (1991). Resource productivity and fisheries management of the northeast shelf ecosystem. In: Sherman, K., Alexander, L. M., Gold, B. D. (eds.) Food chains, yields, models, and management of large marine ecosystems. Westview Press, Inc., Boulder, p. $107-123$

Skjoldal, H. R., Rey, F. (1989). Pelagic production and variability of the Barents Sea ecosystem. In: Sherman, K., Alexander, L. M. (eds.) Biomass yields and geography of large marine ecosystems. AAAS Selected Symp. 111. Westview Press, Inc., Boulder, p. 241-286

Skjoldal, H. R., Noji, T. T., Giske, J., Fossa, J. H., Blindheim, J., Sundby, S. (1993). Mare cognitum. Science Plan for research on marine ecology of the Nordic Seas (Greenland, Norwegian, Iceland Seas) 1993-2000. A regional GLOBEC program with contributions also to WOCE and JGOFS. Institute of Marine Research, Bergen

Smayda, T. (1991). Global epidemic of noxious phytoplankton blooms and food chain consequences in large ecosystems. In: Sherman, K., Alexander, L. M., Gold, B. D. (eds.) Food chains, yields, models, and management of large marine ecosystems. Westview Press, Inc., Boulder, p. 275-308

Smith, W. G., Morse, W. W. (1990). Larval distribution patterns: evidence for the collapse/recolonization of Atlantic herring on Georges Bank. Comm. Meet. int. Coun. Explor. Sea ICES-C.M. 1990/H: 17

Steele, J. H. (1974). The structure of marine ecosystems. Harvard Univ. Press, Cambridge

Steele, J. H. (1988). Scale selection for biodynamic theories. In: Rothschild, B. J. (ed.) Toward a theory on biologicalphysical interactions in the World Ocean, NATO ASI Series C: Mathematical and physical sciences, Vol. 239. Kluwer Academic Publishers, Dordrecht, p. 513-526

Tang, Q. (1989). Changes in the biomass of the Yellow Sea ecosystems. In: Sherman, K., Alexander, L. M. (eds.) Biomass yields and geography of large marine ecosystems. AAAS Selected Symp. 111. Westview Press, Inc., Boulder, p. 7-35

Tang, Q. (1993). Effects of long-term physical and biological perturbations on the contemporary biomass yields of the Yellow Sea Ecosystem. In: Sherman, K., Alexander, L. M., Gold, B. D. (eds.) Large marine ecosystems: stress, mitigation, and sustainability. AAAS Press, Washington, DC, p. 79-93

Taylor, P., Groom, A. J. R. (eds.) (1989). Global issues in the United Nation's framework. Macmillan, London

Terazaki, M. (1989). Recent large-scale changes in the biomass of the Kuroshio Current ecosystem. In: Sherman, K., Alexander, L. M. (eds.) Biomass yields and geography of large marine ecosystems. AAAS Selected Symp. 111. Westview Press, Inc., Boulder, p. 37-65

Ulanowicz, R. E. (1992). Ecosystem health and trophic flow

This review was submitted to the editor networks. In: Costanza, R., Norton, B. G., Haskell, B. D (eds.) Ecosystem health: new goals for environmental management. Island Press, Washington, DC, p. 189-296

UNESCO (United Nations Educational, Scientific and Cultural Organization) (1992). Monitoring the health of the oceans: defining the role of the Continuous Plankton Recorder in global ecosystems studies. The Intergovernmental Oceanographic Commission and The Sir Alister Hardy Foundation for Ocean Science. IOC/INF-869, SC92/WS-8

U.S. Council on Environmental Quality and the Department of State, Gerald O. Barney (director) (1980). The global 2000 report to the president: entering the twenty-first century. Vols. 1-III. U.S. Government Printing Office, Washington, DC

U.S. Dept of Commerce (1988). Folio Map No. 7. A national atlas: health and use of coastal waters, United States of America. U.S. Dept of Commerce, Office of Oceanography and Marine Assessment, Washington, DC

Wei, X., Tong, J., Li, Y. (1993). The pollution state of Huanghai (Yellow Sea) and Bohai Seas and its ecological impact. J. Oceanogr. Huanghai Bohai Seas. 11(3): 82

Williams, R. (1993). Evaluation of new techniques for monitoring and assessing the health of large marine ecosystems. In: Rapport, D. (ed.) NATO advanced research workshop evaluating and monitoring the health of large-scale ecosystems. Springer-Verlag, Berlin (in press)

Williams, R., Aiken, J. (1990). Optical measurements from underwater towed vehicles deployed from ships-ofopportunity in the North Sea. In: Nielsen, H. O. (ed.) Environment and pollution measurement, sensor and systems. Proc. European Congress on Optics (ECO)3, SPIE Vol. 1269. Society of Photo Optical Engineers, Bellingham, WA, p. $186-194$

Wise, J. P. (1984). The future of food from the sea. In: Simon, J. L., Kahn, H. (eds.) The resourceful earth. Basil Blackwell, Inc., New York, p. 113-127

WGEAMS (Working Group on Environmental Assessments and Monitoring Strategies) (1992). Report of the working group on environmental assessments and monitoring strategies. Comm. Meet. int. Coun. Explor. Sea ICESC.M. 1992/Poll: 9, Sess. V. ICES, Copenhagen

Wu, B., Qiu, J. (1993). Yellow Sea fisheries: from single and multi-species management towards ecosystems management. J. Oceanogr. Huanghai Bohai Seas 11(1): 13-17

Wyatt, T., Perez-Gandaras, G. (1989). Biomass changes in the Iberian ecosystem. In: Sherman, K., Alexander, L. M. (eds.) Biomass yields and geography of large marine ecosystems. AAAS Selected Symp. 111. Westview Press, Inc., Boulder, p. 221-239

Zaitsev, Yu. P. (1992). Recent changes in the trophic structure of the Black Sea. Fish. Oceanogr. 1(2): 180-189

Zijlstra, J. J., Baars, M. A. (1990). Productivity and fisheries potential of the Banda Sea Ecosystem. In: Sherman, K. Alexander, L. M., Gold, B. D. (eds.) Large marine ecosystems: patterns, processes, and yields. AAAS Press, Washington, DC, p. 54-65

Manuscript first received: March 4, 1994

Revised version accepted: July 4, 1994 